\title{
Piperaceae em um fragmento de floresta atlântica da Serra da Mantiqueira, Minas Gerais, Brasil
}

Piperaceae in a fragment of atlantic florest of the Serra da Mantiqueira, Minas Gerais, Brazil

\author{
Daniele Monteiro ${ }^{1,2}$
}

\begin{abstract}
Resumo
A Serra Negra localiza-se em Minas Gerais (2158’24’S e 4353'15’W), entre as Serras do Ibitipoca e o Maciço do Itatiaia, abrangendo uma área da Serra da Mantiqueira considerada prioritária para a conservação e investigação científica. Com o objetivo de ampliar o conhecimento florístico da região, foi realizado o tratamento florístico das Piperaceae ocorrentes. Foram registradas 34 espécies da família, a grande maioria em formações florestais, incluindo cânions. Contribuíram para a identificação dos táxons o hábito, presença ou ausência de tricomas, filotaxia, forma, dimensão e padrão de nervação foliar, tipo de inflorescência, número de estames e carpelos, presença de estilete, além da forma da bractéola e fruto. Piper pauciramosum, endêmico de Minas Gerais e até o momento conhecido apenas pelo material tipo, foi encontrado na região e precisa ter o estado de conservação reavaliado, assim como outras 10 espécies consideradas raras. A ocorrência desses táxons e de outros com distribuição restrita aumentam a importância de região e a necessidade de implantação de unidades de conservação.
\end{abstract}

Palavras-chave: Florística, Peperomia, Piper, Serra Negra, Taxonomia.

\begin{abstract}

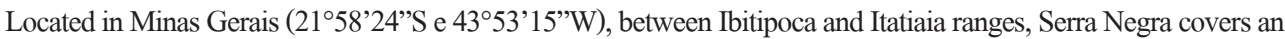
area considered priority for conservation and scientific research at Serra da Mantiqueira. Continuing the studies at the area aiming to increase floristic knowledge of the region, the taxonomic treatment of Piperaceae was held. Thirty four species of the family were recorded, most of them in forested formations, including canyons. The taxa are distinguished by habit, presence or absence of trichomes, phyllotaxis, leaf size, form and venation, type of inflorescence, number of stamens and carpels, presence of style, shape of bracteoles and fruits. Piper pauciramosum, endemic to Minas Gerais and only known from type material was collected and needs a re-evaluation of its conservation status, as well as 10 other species considered to be rare. The occurrence of these taxa and others species with restricted distribution highlights the importance of this region and points out the great need of new conservation units at the area.
\end{abstract}

Key words: Floristic, Peperomia, Piper, Serra Negra.

\section{Introdução}

Piperaceae possui cerca de 3.600 espécies (Smith et al. 2008) com distribuição pantropical, sendo a América do Sul um dos maiores centros de diversidade (Yuncker 1958). Em todo o mundo, várias espécies são cultivadas como ornamentais ou utilizadas tradicionalmente na alimentação e na medicina caseira (Guimarães et al. 1992; Pessini et al. 2003), bem como nas indústrias farmacêuticas, de cosméticos e de inseticidas (Silva \& Machado 1999). Atualmente são reconhecidos cinco gêneros, subdivididos em três subfamílias: Verhuellia Miq. (Verhuellioideae), Zippelia Blume e Manekia Trel. (Zippelioideae), Piper L. e Peperomia Ruiz \& Pav. (Piperoideae), que são os dois maiores gêneros em número de representantes, com aproximadamente 1500 espécies cada (Samain et al. 2008). Os três últimos gêneros são encontrados no Brasil, principalmente em florestas úmidas nos domínios amazônico e atlântico (Yuncker 1972, 1973, 1974; Guimarães et al. 2011).

A Serra Negra representa um remanescente de floresta atlântica, situado em uma área da Serra da Mantiqueira considerada prioritária para a conservação

\footnotetext{
Instituto de Pesquisas Jardim Botânico do Rio de Janeiro, Diretoria de Pesquisa Científica, R. Pacheco Leão 915, Jardim Botânico, 22460-030, Rio de Janeiro, Brasil.

${ }^{2}$ Autora para correnpondência: danielepiper1@gmail.com
} 
e indicada para a implantação de unidades de conservação e investigação científica (Costa et al. 1998; Drummond et al. 2005). Localizada na Zona da Mata de Minas Gerais (2158'24'S e 4353'15'W), suas serras abrangem parte de cinco municípios (Bom Jardim de Minas, Lima Duarte, Olaria, Rio Preto e Santa Bárbara do Monte Verde - mapa em MeniniNeto et al. 2009), formando um corredor florístico entre a Serra de Ibitipoca e o Maciço do Itatiaia (Fig. 1), além de ser adjacente à APA da Mantiqueira (Menini Neto et al. 2009; Valente et al. 2011). Sua vegetação é formada por campos com afloramentos quartizíticos e florestas (aluvial periodicamente inundável, ombrófila densa montana e alto montana), em gradientes altitudinais variando de 960 a $1698 \mathrm{~m}$ (Valente et al. 2011).

Este trabalho teve como objetivo ampliar o conhecimento florístico da Serra Negra, através do estudo taxonômico das espécies de Piperaceae ocorrentes, dando continuidade às investigações científicas que vem sendo realizadas na região (Menini Neto et al. 2009; Abreu \& Menini Neto 2010; Abreu et al. 2011; Feliciano \& Salimena 2011; Valente et al. 2011).

\section{Material e Métodos}

Expedições de campo foram realizadas de 2003 a 2010, pela equipe do herbário Leopoldo Krieger (CESJ), para amostragem de espécies vegetais ocorrentes na área de estudo, tendo sido

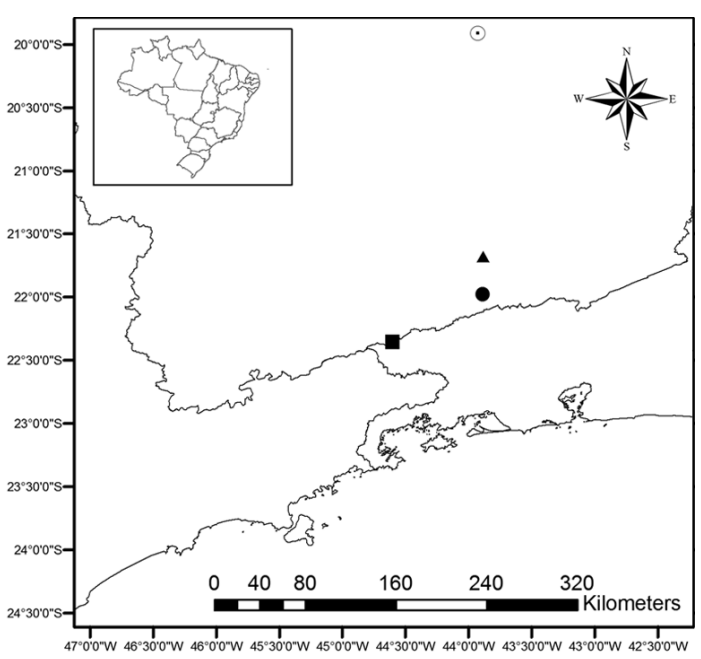

Figura 1 - Mapa de localização da área de estudo: Serra Negra (círculo), entre o Parque Estadual de Ibitipoca (triangulo) e o Parque Nacional do Itatiaia (quadrado). Figure 1 - Location map of the study area: Serra Negra (circle), between the Parque Estadual do Ibitipoca (triangle), and the Parque Nacional do Itatiaia (square). intensificadas as coletas de exemplares férteis de Piperaceae nos três últimos anos. Os materiais foram depositados no herbário CESJ e as duplicatas enviadas a outras instituições.

Foram produzidas descrições e comentários sobre utilidades, denominações populares e distribuição geográfica das espécies, além de uma chave para identificação de todos os táxons, apresentados em ordem alfabética, assim como os municípios citados no material examinado.

Para as ilustrações foram priorizados táxons pouco conhecidos e/ou pobremente ilustrados.

\section{Resultados e Discussão}

Foram registradas 34 espécies de Piperaceae na Serra Negra, das quais 14 são de Peperomia e 20 pertencem ao gênero Piper. Os representantes de Piper apresentam-se na região como arbustos aromáticos, com nós bem marcados e profílos persistentes ou caducos. As folhas são alternas, com venação geralmente pinada (acródroma em P. amalago L.), e as inflorescências são opostas às folhas, com as flores possuindo 2-6 estames, caducos e muitas vezes de difícil visualização em material herborizado. Os carpelos são de 3-4, podendo o estilete estar ou não presente. As espécies de Peperomia caracterizam-se como ervas frequentemente carnosas e estoloníferas, terrestres, epífitas ou rupícolas. Possuem folhas alternas, opostas ou verticiladas, dois estames, dispostos lateralmente na base do pistilo, e ovário unicarpelar, unilocular, com um único estigma. $\mathrm{O}$ único padrão de venação foliar observado foi do tipo acródromo-basal, com nervuras variando de 3-7, e as bractéolas florais são arredondado-peltadas, glandulosas e glabras.

Todas as espécies de Piper foram observadas em formações florestais, enquanto as de Peperomia foram encontradas em sua maioria em áreas de floresta úmida, incluindo cânions (fragmentos de floresta perenifólia rupícola), e em afloramentos quartizíticos (Peperomia augescens Miq., P. blanda (Jacq.) Kunth, $P$. galiodes Kunth e duas variedades de P. tetraphylla (G. Forst) Hook \& Arn.). O Cânion do Funil, Ninho da Égua, Marciano e Serra da Caveira D'Anta, no município de Rio Preto, e a RPPN Fazenda Serra Negra, em Lima Duarte, estão entre as principais áreas onde foram coletados táxons da família. Com o Parque Estadual de Ibitipoca (Medeiros \& Guimarães 2007) e o Parque Nacional de Itatiaia (Monteiro \& Guimarães 2008, 2009), com quem a Serra Negra parece formar um corredor florístico, possui em comum duas e 13 espécies da 
família respectivamente; outras 12 espécies são comuns às três áreas.

Entre os táxons que possuem distribuição restrita, Piper cubataonum C.DC., P. duartei E.F. Guim. \& M. Carvalho-Silva, P. pseudopothifolium C.DC. e P. claussenianum (Miq.) C.DC. ocorrem apenas no Sudeste do Brasil. Peperomia augescens, P. corcovadensis Gardner, P. diaphanoides Dahlst., P. mandioccana Miq., P. pseudoestrellensis C.DC. e Piper lhotzkyanum Kunth são encontrados no Sudeste e Sul do país, enquanto Piper anisum (Spreng.) Angely nas Regiões Nordeste e Sudeste. Peperomia martiana Miq. e P. trinervis Ruiz \& Pav. ocorrem de forma disjunta nas regiões amazônica e atlântica. Os demais táxons se estendem por três ou mais regiões brasileiras ou possuem ampla distribuição.
Piper pauciramosum Yunck., endêmica de Minas Gerais e até o momento conhecida apenas na localidade típica, ressalta a importância da área de estudo, assim como a presença de táxons raros que precisam ter o estado de conservação reavaliado, para inclusão nas listas de espécies ameaçadas de extinção, como Peperomia augescens Miq., P. diaphanoides Dahlst., P. mandioccana Miq., P. pseudoestrellensis C.DC., P. trinervis Ruiz \& Pav., Piper claussenianum (Miq.) C.DC., P. duartei E.F. Guim. \& M. Carvalho-Silva, P. coccoloboides Kunth, P. pauciramosum Yunck. e P. viminifolium Trel. Peperomia urocarpa Fisch \& C.A. Mey, ao contrário, foi citada na lista de espécies ameaçadas de extinção de Minas Gerais, porém possui ampla e expressiva distribuição, sendo bastante comum em florestas úmidas, recomendando-se aqui a exclusão do táxon da lista de espécies ameaçadas.

\section{Chave para identificação dos gêneros e espécies de Piperaceae ocorrentes na Serra Negra}

1. Ervas, 1 estigma

Peperomia

2. Folhas alternas.

3. Ramos glabros.

4. Folhas mais concentradas no ápice dos ramos, ápice obtuso a arredondado, emarginado

9. P. martiana

4'. Folhas distribuídas por todo o ramo, ápice agudo ou acuminado, não emarginado.

5. Folhas da base geralmente diferentes das do ápice, ápice cerdoso e contraído ......

2. P. augescens

5'. Folhas da base iguais as do ápice, ápice ciliado, não contraído.

6. Ramos alados; folhas com mais de $5 \mathrm{~cm}$ compr.

1. P. alata

6'. Ramos não alados; folhas com menos de $5 \mathrm{~cm}$ compr.

5. P. diaphanoides

3'. Ramos com tricomas.

7. Folhas com mais de $2,5 \mathrm{~cm}$ compr.

8. Folhas ovadas, pubescentes; pedúnculo $2-3 \mathrm{~cm}$ compr.

14. P. urocarpa

8'. Folhas elíptico-lanceoladas, vilosas; pedúnculo até $1 \mathrm{~cm}$ compr.

13. P. trinervis

7. Folhas com menos de $2,5 \mathrm{~cm}$ compr.

9. Ramos longo-vilosos; folhas com ápice obtuso a arredondado, emarginado; fruto com ápice oblíquo, sem pseudocúpula basal

11. P. rotundifolia

9'. Ramos hirtos, hirtelos ou curto-vilosos; folhas com ápice agudo, não emarginado; fruto com ápice agudo e pseudocúpula basal.

10. Folhas glabras em ambas as faces

8. P. mandioccana

10'. Folhas com tricomas em uma ou ambas as faces.

11. Folhas com mais de $5 \mathrm{~mm}$ larg.; espigas 2,5-4 cm compr.

4. $P$. corcovadensis

11'. Folhas até $5 \mathrm{~mm}$ larg.; espigas com menos de $1 \mathrm{~cm}$ compr.

10. P. pseudoestrellensis

2'. Folhas opostas ou verticiladas.

12. Planta vilosa.

13. Folhas com mais de $1 \mathrm{~cm}$ compr., as da base diferentes das do ápice; espigas $5-12 \mathrm{~cm}$ compr.; fruto com ápice oblíquo, sem pseudocúpula basal 3. P. blanda

13'. Folhas até $1 \mathrm{~cm}$ compr., iguais da base ao ápice; espigas ca. $1,5 \mathrm{~cm}$ compr.; fruto com ápice agudo e pseudocúpula basal

7. P. glazioui 
12'. Planta hirta ou hirtela.

14. Folhas oblongas a oblongo-lanceoladas; espigas quatro vezes mais longas do que as folhas; raque glabra; fruto com ápice oblíquo, sem pseudocúpula basal 6. P. galioides

14'. Folhas rômbico-ovadas a rômbico-elípticas; espigas duas vezes mais longas do que as folhas; raque pilosa; fruto com ápice agudo e pseudocúpula basal

12. P. tetraphylla

1'. Arbustos, 3-4 estigmas Piper

15. Folhas com nervação acródroma-basal 15. P. amalago

15'. Folhas com nervação camptódroma ou broquidódroma, ou eucamptódroma.

16. Inflorescências em racemo.

17. Folhas glabras em ambas as faces

23. P. corcovadensis

17'. Folhas com tricomas, em uma ou ambas as faces.

18. Folhas glabras na face adaxial e hirtelas ao longo das nervuras na face abaxial; racemos com mais de $6 \mathrm{~cm}$ compr. 16. P. anisum

18'. Folhas vilosas em ambas as faces; racemos com menos de $6 \mathrm{~cm}$ compr.

25. P. duartei

16'. Inflorescências em espiga.

19. Folhas com nervuras secundárias dispostas até o ápice.

20. Folhas simétricas a ligeiramente assimétricas na base; fruto trigonal ou ovóide.

21. Folhas ovadas; pecíolo com mais de $2 \mathrm{~cm}$ compr., com bainha alada em toda sua extensão; espigas 5-7 cm compr. 32. P. solmsianum

21'. Folhas lanceoladas ou oblongo-lanceoladas; pecíolo com menos de $2 \mathrm{~cm}$ compr., sem bainha alada; espigas até $5 \mathrm{~cm}$ compr.

22. Ramos e folhas com glândulas castanhas; bractéola franjada na com glândulas castanhas, margem; fruto ovóide com estilete curto

18. P. caldense

22'. Ramos e folhas sem glândulas castanhas; bractéola glabra; fruto trigonal; estilete ausente 34. P. viminifolium

20'. Folhas fortemente assimétricas na base; fruto oblongo.

23. Ramos glabros

31. P. richardiifolium

23'. Ramos com tricomas.

24. Folhas com mais de $10 \mathrm{~cm}$ larg., ovado-elípticas, elípticas.

25. Face adaxial das folhas tomentoso-vilosa, abaxial vilosa

22. P. coccoloboides

$25^{\prime}$. Face abaxial das folhas tomentoso-pubescente, adaxial glabra

19. P. cernuum

24'. Folhas com menos de $10 \mathrm{~cm}$ larg., lanceoladas.

26. Ramos pubérulos; espigas 6-8 cm compr., eretas

17. P. arboreum var. hirtellum

26'. Ramos vilosos; espigas 13-21 cm compr., pêndulas

30. P. pseudopothifolium

19'. Folhas com nervuras secundárias dispostas até a porção mediana.

27. Ramos e folhas glabros; fruto com estilete

27. P. lhotzkyanum

27'. Ramos e folhas com tricomas; fruto sem estilete.

28. Pecíolo até $1,5 \mathrm{~cm}$ compr.

29. Folhas 3-4 vezes mais longas do que largas; frutos glabros.

30. Folhas revolutas, buladas, com a base obtusa em ambos os lados e face abaxial com tricomas não adpressos; pedúnculo $1-1,5 \mathrm{~cm}$ compr.

20. P. chimonanthifolium

30'. Folhas não revolutas, não buladas, com a base aguda em um dos lados e face abaxial com tricomas adpressos; pedúnculo ca. $1 \mathrm{~cm}$ compr. 26. $P$. gaudichaudianum

29'. Folhas até 2 vezes mais longas do que largas; frutos com tricomas.

31. Folhas ásperas ao toque e buladas quando envelhecida.

32. Ramos vilosos, não retrosos; face abaxial da folha sem tricomas adpressos 21. P. claussenianum 
32'. Ramos retrorso-pubescentes; face abaxial da folha com tricomas adpressos 29. P. pauciramosum

31'. Folhas sedosas ao tato, não buladas quando envelhecidas 28. P. mollicomum 28'. Pecíolo mais de $1,5 \mathrm{~cm}$ compr.

33. Ramos longo-vilosos; espigas até $6 \mathrm{~cm}$ compr.; bractéola glabra; fruto trigonal, glabro 24. P. cubataonum

33'. Ramos pubescentes; espigas acima de $8 \mathrm{~cm}$ compr.; bractéola franjada; fruto oblongo, pubescente 33. P. tectoniifolium

1. Peperomia alata Ruiz \& Pav., Fl. Peruv. 1: 31, tab. 48, fig. b. 1798.

Rupícola ou terrestre, glabra; ramos decumbentes, alados. Folhas alternas, distribuídas por todo o ramo, iguais da base ao ápice, 5-10 $\times 2-3,5 \mathrm{~cm}$, elípticas a ovado-lanceoladas, base aguda, ápice acuminado, ciliado, não emarginado, não contraído; nervuras 3-5; pecíolo $0,5-1 \mathrm{~cm}$ compr.; Espigas 7-13 cm compr., axilares ou terminais, $1-2$, eretas; pedúnculo $0,5-1,5 \mathrm{~cm}$ compr.; raque foveolada, lisa. Fruto globosoovóide, com ápice oblíquo e estigma subapical. Material selecionado: Rio Preto, Vilarejo do Funil, Cânion Ribeirão do Funil, 21.V.2004, fl., F.R.G. Salimena et al. 1285 (CESJ, RB); 10.XI.2005, fr., $K$. Antunes et al. 193 (CESJ, RB).

Peperomia alata já teve seus caracteres diagnósticos ilustrados (Monteiro \& Guimarães 2008), sendo facilmente reconhecida pelos ramos decumbentes e alados, folhas alternas com ápice acuminado, ciliado e pelas espigas tão longas quanto as folhas. Possui ampla distribuição, ocorrendo da América Central até o Sul do Brasil (Guimarães 1999). Na Serra Negra foi encontrada a ca. $900 \mathrm{~m}$ altitude, em interior de mata úmida e sombreada. Floresce e frutifica praticamente todo o ano.

\section{Peperomia augescens Miq., Arch. Neerl. 6:} 171. 1871.

Epífita ou terrestre, glabra; ramos eretos ou ascendentes, vináceos. Folhas alternas, distribuídas por todo o ramo, as da base do ramo diferentes das do ápice, $2-5 \times 1,3-2,5 \mathrm{~cm}$, rômbico-ovadas, ovadas, ovado-oblongas, lanceoladas, lanceoladooblongas, lustrosa na face adaxial, vinácea na abaxial, base cuneada, ápice agudo-acuminado, contraído, cerdoso, não emarginado; nervuras 3 , impressas na face adaxial; pecíolo $0,5-1 \mathrm{~cm}$ compr. Espigas 10-16 cm compr., terminais, 1-4, eretas ou flexuosas, verde-claras; pedúnculo 1-2 cm compr.; raque foveolada, lisa. Fruto globoso-ovóide com ápice oblíquo e estigma subapical.
Material selecionado: Lima Duarte, estrada para Monte Verde de Cima, 21 ${ }^{\circ} 56^{\prime} 33^{\prime \prime} \mathrm{S} 43^{\circ} 44^{\prime} 27^{\prime \prime} \mathrm{W}$, 15.X.2008, fl., F.R.G. Salimena \& P.H. Nobre 2763 (CESJ). Olaria, Serrinha, Sítio do Rinaldo, 28.VII.2009, fl. e fr., F.S. Souza et al. 743 (CESJ). Rio Preto, Ninho da Égua, trilha para o Cânion do Funil, 3.II.2009, f1., D. Monteiro et al. 498 (CESJ); trilha atrás da Gruta do Funil, 3.II.2009, fl. e fr., D. Monteiro et al. 504 (CESJ); trilha para a Cachoeira do Marciano, 4.II.2009, fl., D. Monteiro et al. 508 (CESJ); trilha para o Ninho da Égua, 2.V.2009, fl. e fr., D. Monteiro et al. 535 (CESJ).

Peperomia augescens, ilustrada recentemente (Medeiros \& Guimarães 2007), diferencia-se das demais espécies estudadas pelas folhas alternas, com ápice cerdoso e contraído, sendo as da base geralmente diferentes das do ápice, e pelo tamanho das espigas, frequentemente três vezes maiores do que as folhas. É uma planta rara que ocorre de forma esparsa em Goiás e em algumas regiões do Sudeste e Sul do Brasil (Guimarães et al 2007; Monteiro \& Guimarães 2008). Na área de estudo foi encontrada no interior de mata úmida e também em áreas de transição para campo com solo quartizítico. Floresce e frutifica praticamente todo o ano.

3. Peperomia blanda (Jacq.) Kunth, Nov. Gen. Sp. 1: 67. 1816.

Terrestre ou rupícola; ramos eretos, vináceos, densamente vilosos, tricomas $0,5-1 \mathrm{~mm}$ compr. Folhas opostas a 3-verticiladas, as da base diferentes das do ápice, 2,5-5,5 × 1,3-2,5 cm, elípticas, eliptico-lanceoladas, rômbico-elipticas, obovadas, base aguda, decorrente, ápice agudo a acuminado raramente obtuso, vilosa em ambas as faces, vináceas na face abaxial; margem ciliada na metade superior; nervuras 5-7; pecíolo $0,5-1$ cm compr., densamente viloso. Espigas 5-12 cm compr., axilares e terminais, 1-3, eretas; pedúnculo 1-2 cm compr., viloso; raque foveolada, ligeiramente verrucosa, glabra. Fruto globosoovóide, com ápice oblíquo e estigma subapical, sem pseudocúpula basal. 
Material selecionado: Rio Preto, trilha para a Cachoeira do Marciano, 21.IV.2005, fr., K. Antunes et al. 156 (CESJ, RB); Cânion do Funil, IV.2006, fl., N.L. Abreu et al. 71 (CESJ); trilha para a Cachoeira da Água Amarela, 17.III.2007, fl., N.L. Abreu et al. 156 (CESJ, RB); trilha para o Ninho da Égua, 2.V.2009, fl. e fr., D. Monteiro et al. 534 (CESJ). Santa Bárbara do Monte Verde, Fazenda Cachoeira Alta, 2157'57'W, 4350'21'S, 1072 m., 10.II.2007, fr., F.R.G. Salimena \& P.H. Nobre 2395 (CESJ, RB).

Peperomia blanda caracteriza-se pelos tricomas vilosos, espigas longas e folhas opostas que variam quanto à forma e tamanho no mesmo ramo. Distribui-se nas Américas Central e do Sul. No Brasil ocorre comumente em Roraima, Ceará, Pernambuco, Paraíba, Alagoas, Bahia, Mato Grosso, Mato Grosso do Sul, Goiás, Distrito Federal e em todos os estados das Regiões Sudeste e Sul (Monteiro \& Guimarães 2008; CRIA 2009, SpeciesLink). Na Serra Negra foi encontrada em borda, interior de mata e em campo com solo arenoso ou quartizítico. Floresce e frutifica de janeiro a maio. Ilustração em Steyermark (1984).

4. Peperomia corcovadensis Gardner, London J. Bot. 1: 187. 1842.

Epífita; ramos ascendentes, hirtelos a glabrescentes. Folhas alternas, 1-2,3 × 0,7-1,2 cm, ovado-elípticas, elíptico-lanceoladas, base aguda, ápice agudo, não emarginado, face adaxial glabra, lustrosa, abaxial glabrescente a hirtela ao longo da nervura central; nervuras 3; pecíolo 2-5 mm compr., hirtelo. Espigas 2,5-4 cm compr., terminais, solitárias, eretas; pedúnculo 1,5-2 cm compr., hirtelo; raque foveolada, verrucosa e glabra. Fruto elíptico-ovóide, com ápice agudo, estigma apical e pseudocúpula basal.

Material selecionado: Lima Duarte, RPPN Fazenda Serra Negra, 25.X.2008, fl. e fr., D. Monteiro et al. 385 (CESJ). Rio Preto, Burro de Ouro, 27.VII.2006, fl. e fr., C.N. Matozinhos et al. 289 (CESJ).

Peperomia corcovadensis pode ser reconhecida pelo pequeno porte, ramos hirtelos, folhas sempre alternas, geralmente ovadas e espigas eretas. Diferencia-se de $P$. mandioccana Miq. pela filotaxia e presença de tricomas na face abaxial das folhas; de $P$. pseudoestrellensis C.DC. difere por possuir maiores o comprimento das espigas e a dimensão das folhas. Ocorre apenas nas Regiões Sudeste e Sul do Brasil, sendo bastante frequente (Guimarães 1994). Na região é facilmente encontrada no interior de mata, florescendo e frutificando de julho a outubro.
5. Peperomia diaphanoides Dahlst., Kongl. Svenska Vetensk. Acad. Handl. 33(2): 112, tab 10, fig. 3,4. 1900.

Epífita, glabra; ramos eretos, não alados. Folhas alternas, distribuídas por todo o ramo, as da base iguais as do ápice, 3,5-4 × 1,7-2,5 cm, ovadas, ovado-elípticas, base aguda a obtusa, ápice agudo-acuminado, não emarginado, não contraído; margem ciliada na metade superior; nervuras 3-5; pecíolo ca. $1 \mathrm{~cm}$ compr. Espigas 6-10 cm compr., terminais, 1-3, eretas; pedúnculo 1-1,5 cm compr.; raque foveolada, lisa. Fruto globoso-ovóide, oblíquo no ápice e estigma subapical.

Material examinado: Rio Preto, trilha para o Ninho da Égua, 27.I.2007, fl., L. Menini Neto et al. 281 (CESJ, RB); trilha para a cachoeira do Marciano, 4.II.2009, fl. e fr., D. Monteiro et al. 506 (CESJ).

Peperomia diaphanoides, ilustrada em Monteiro \& Guimarães (2008), caracteriza-se por ser totalmente glabra, exceto pela presença de tricomas na metade superior da margem das folhas, que são sempre alternas. Pode ser confundida com $P$. augescens, da qual difere pelas folhas ciliadas com ápice não contraído, sendo iguais em todo o ramo; de $P$. alata diferencia-se pelos ramos não alados e folhas menores. Tratase de planta rara, encontrada de forma esparsa em algumas áreas do Sudeste e Sul do Brasil (Monteiro \& Guimarães 2008).

6. Peperomia galioides Kunth, Nov. Gen. Sp. 1: 71, tab. 17. 1816.

Terrestre; ramos eretos ou ascendentes, ditricotomicos, vináceos, hirtelos a glabrescentes. Folhas 3-7 verticiladas, $1-2 \times 0,3-0,5 \mathrm{~cm}$, oblongas, oblongo-lanceoladas, base aguda, ápice obtuso, ciliado, glabra em ambas as faces; nervuras 3; pecíolo ca. $1 \mathrm{~mm}$ compr., hirtelo. Espigas 4-8 cm compr., terminais, 1-5, flexuosas; pedúnculo 3-5 mm compr., hirtelo; raque foveolada, lisa, glabra. Fruto ovóide, oblíquo no ápice, com estigma subapical, sem pseudocúpula basal.

Material selecionado: Rio Preto, Cânion do Funil, 3.II.2009, fl. e fr., D. Monteiro et al. 497 (CESJ); trilha para o ninho da égua, 2.V.2009, fl. e fr., D. Monteiro et al. 533 (CESJ).

Peperomia galioides é facilmente reconhecida pelos ramos eretos, di-tricotomicamente ramificados e hirtelos, folhas 3-7 verticiladas e espigas até quatro vezes mais longas do que as folhas, como recentemente ilustrado (Medeiros \& Guimarães 2007). Possui ampla distribuição, ocorrendo do México até o Sul do Brasil (Monteiro 
\& Guimarães 2008). Na Serra Negra foi encontrada apenas em áreas de campo sobre solo quartizítico. Floresce e frutifica todo o ano.

7. Peperomia glazioui C.DC., Linnaea 37: 380. 1872.

Epífita, longo-vilosa, tricomas $0,5-1 \mathrm{~mm}$ compr; ramos ascendentes, quadrangulares, articulados, com sulcos profundos quando secos e nós densamente vilosos. Folhas opostas, as da base iguais as do ápice, 5-10 × 6-9 mm, ovadoorbiculares, obovado-elípticas, base obtusa, ápice obtuso a arredondado, face abaxial vilosa com tricomas mais concentrados na base, face adaxial glabra; margem ciliada; nervuras 3 ; pecíolo ca. 1 $\mathrm{mm}$ compr., viloso. Espigas ca. 1,5 cm compr., terminais, solitárias, eretas; pedúnculo 1-1,4 $\mathrm{cm}$ compr., esparso viloso a glabrescente, raque foveolada, verrucosa, glabra. Fruto elíptico com ápice agudo, estigma apical e pseudocúpula basal. Material examinado: Rio Preto, Pousada Fazenda Mato limpo, Gruta dos Macacos, 28.II.2007, fl. e fr., N.L. Abreu et al. 136 (CESJ); cachoeira da Água Amarela, 17.III.2007, fl., N.L. Abreu et al. 147 (CESJ, RB).

Peperomia glazioui possui ramos quadrangulares, articulados e longo vilosos, folhas opostas, ovado-orbiculares a obovado-elípticas e espigas curtas, como ilustrado em Monteiro \& Guimarães (2008). É pouco frequente e possui distribuição restrita às florestas úmidas das Regiões Sudeste e Sul do Brasil (Guimarães et al. 1984).

8. Peperomia mandioccana Miq., Linnaea 20: 125. 1847.

Epífita ou rupícola; ramos $10-15 \mathrm{~cm}$ alt., eretos, hirtelos. Folhas alternas na base, opostas a ocasionalmente ternadas no ápice, 1,3-1,7 $\times$ $0,7-1,2 \mathrm{~cm}$, ovadas a ovado-elípticas, base aguda a obtusa, ápice agudo, não emarginado, glabra em ambas as faces; margem ciliada; nervuras 3 ; pecíolo 4-6 mm compr., hirtelo. Espigas 2-3 cm compr., terminais, solitárias, eretas; pedúnculo $0,7-1,3 \mathrm{~cm}$ compr., hirtelo; raque verrucosa, foveolada, glabra. Fruto oblongo com ápice agudo, estigma apical e pseudocúpula basal.

Material examinado: Rio Preto, Burro de Ouro, 21 ${ }^{\circ} 58^{\prime} 11^{\prime \prime}$ 'S 4353'21'W, 20.V.2006, fl. e fr., P.L. Viana 2056 (CESJ); trilha da cachoeira do Marciano, 4.II.2009, fr., D. Monteiro et al. 515 (CESJ).

Peperomia mandioccana pode ser reconhecida pelo porte pequeno e filotaxia alterna na base e oposta a ternada no ápice, como ilustrado recentemente (Mederios \& Guimarães
2007). Assemelha-se morfologicamente a $P$. corcovadensis diferindo por apresentar filotaxia variada no mesmo ramo, folhas ciliadas, porém glabras em ambas às faces, além de espigas e pedúnculos ligeiramente menores. Pode ser considerada rara por ocorrer de forma esparsa em florestas úmidas de alguns estados do Sudeste do Brasil (Monteiro \& Guimarães 2008).

9. Peperomia martiana Miq., Syst. Piperac. 1: 189. 1843.

Epífita ou rupícola, glabra; ramos eretos. Folhas alternas, mais concentradas no ápice dos ramos, $1,5-2 \times 1-1,5 \mathrm{~cm}$, obovadas, elípticoobovadas, base decorrente, ápice obtuso a arredondado, emarginado, cerdoso; nervuras 5, impressas na face adaxial; pecíolo 4-10 mm compr. Espigas ca. $2 \mathrm{~cm}$ compr., terminais, solitárias, eretas; pedúnculo ca. $2 \mathrm{~cm}$ compr.; raque lisa, foveolada, glabra. Fruto globoso a ovóide, com ápice oblíquo e estigma subapical.

Material selecionado: Rio Preto, Funil, Serrote de São Gabriel, 2.VI.2006, fl., F.R.G. Salimena et al. 1359 (CESJ, RB); Cânion do Funil, 3.II.2009, fl. e fr., D. Monteiro et al. 501 (CESJ).

Peperomia martiana diferencia-se facilmente das demais espécies ocorrentes na região por ser uma erva glabra com folhas alternas e obovadas, com ápice emarginado, mais concentradas no ápice dos ramos. Ocorre de forma disjunta, da Nicarágua até o Peru e nas Regiões Sudeste e Sul do Brasil, onde é pouco frequente (Monteiro \& Guimarães 2008). Na Serra Negra foi encontrada no interior de mata úmida, próximo a riacho. Coletada com flor em fevereiro, abril e junho, e com fruto em fevereiro. Ilustração em Steyermark (1984).

10. Peperomia pseudoestrellensis C.DC., Annuaire Conserv. Jard. Bot. Genève 2: 277. 1898.

Epífita, hirta a curto vilosa, tricomas ca. 0,2 mm compr.; ramos delicados, hirtos. Folhas alternas, ca. $1 \times 0,5 \mathrm{~cm}$, lanceoladas a elíptico-lanceoladas, base aguda, ápice agudo, não emarginado, hirta em ambas as faces; margem ciliada; nervuras 3 ; pecíolo 1-3 mm compr., curto-viloso. Espigas 5-7 mm compr., terminais, solitárias; pedúnculo 6-9 mm, hirto; raque foveolada, verrucosa, glabra. Fruto elíptico-ovado a elíptico, com ápice agudo, estigma apical e pseudocúpula basal.

Material examinado: Rio Preto, Cânion do Funil, 21.V.2004, fl. e fr., F.R.G. Salimena et al. 1340 (CESJ, RB).

Peperomia pseudoestrellensis é pequena e delicada, difícil de ser visualizada e coletada. 
Possui como caracteres diagnósticos os tricomas hirtos, distribuídos por toda a planta, as folhas pequenas, alternas, e lanceoladas, além das espigas e pedúnculos curtos, como ilustrado em Monteiro \& Guimarães (2008). É rara e pouco frequente, possuindo distribuição restrita as Regiões Sudeste e Sul do Brasil (Guimarães \& Giordano 1997). Na área de estudo foi coletada apenas no Cânion do Funil, florescendo e frutificando em maio.

11. Peperomia rotundifolia (L.) Kunth, Nov. Gen. Sp. 1: 65. 1815.

Epífita, reptante, delicada; ramos longo vilosos, tricomas $0,5-1 \mathrm{~mm}$ compr. Folhas alternas, 5-10 × 3-5 mm, elíptico-obovadas, elípticoarredondadas, base aguda a obtusa, ápice obtuso a arredondado, emarginado, vilosa em ambas as faces; margem ciliada, nervuras 3 ; pecíolo $2-5 \mathrm{~mm}$ compr., viloso a glabrescente;. Espigas 1-1,5 cm compr., axilares ou terminais, solitárias; pedúnculo ca. 5 $\mathrm{mm}$ compr., glabrescente; bráctea peduncular $1-1,5$ mm compr., basal, espatulada, vilosa, membranácea, glandulosa; raque foveolada, verrucosa, glabra. Fruto elíptico-ovóide, com ápice oblíquo e estigma subapical, sem pseudocúpula basal.

Material selecionado: Rio Preto, Vilarejo do Funil, 21.V.2004, fl., F.R.G. Salimena et al. 1335 (CESJ, RB); Cânion do Funil, 19.IV.2009, fl. e fr., L. Menini Neto et al. 663 (CESJ).
Peperomia rotundifolia é uma erva epífita, delicada, vilosa, com folhas elíptico-obovadas a elíptico-arredondadas, de ápice emarginado. $\mathrm{O}$ táxon teve estes e outros caracteres diagnósticos ilustrados recentemente, possuindo ampla distribuição (Monteiro \& Guimarães 2008). Na região foi coletada em área de mata úmida e sombreada. Floresce e frutifica de novembro a maio.

12. Peperomia tetraphylla (G. Forst.) Hook. \& Arn., Bot. Beechey Voy. 97. 1832.

Epífita ou terrestre; ramos ascendentes ou eretos, hirtos a glabrescentes, tricomas ca. 0,2 mm compr. Folhas 4-verticiladas, 6-13 × 4-9 mm, rômbicoovadas a rômbico-elípticas, base obtusa, ápice agudo a obtuso, às vezes contraído e cerdoso, hirta a glabrescente em ambas as faces; margem por vezes ciliada; nervuras 3; pecíolo ca. $2 \mathrm{~mm}$ compr. hirto a glabrescente;. Espigas 1,5-2,5 cm compr., terminais ou axilares, 1-3 eretas; pedúnculo 1-2 $\mathrm{cm}$ compr., hirto; raque densamente pilosa. Fruto elíptico, com pseudocúpula basal, ápice agudo e estigma apical.

Peperomia tetraphylla é de fácil reconhecimento pela filotaxia 4-verticilada, folhas rômbicas e coriáceas, raque pilosa e frutos com pseudocúpula basal. $\mathrm{Na}$ área de estudo foram encontradas três variedades, cujos principais caracteres diagnósticos, presença e tipo de tricoma nos ramos e folhas, foram recentemente ilustrados (Medeiros \& Guimarães 2007).

\section{Chave de identificação para as variedades de $P$. tetraphylla ocorrentes na Serra Negra}

1. Lâmina foliar glabra em ambas as faces, cerdosa no ápice ou ciliada apenas na metade superior ........ 12.3. P. tetraphylla var. valantoides

1'. Lâmina foliar com tricomas em uma ou ambas as faces, ciliada em toda a margem.

2. Ramos com tricomas hirtos da base até o ápice

2'. Ramos com tricomas hirtos no ápice e longo vilosos na base 12.2. P. tetraphylla var. tetraphylla

12.1. P. tetraphylla var. tenera

12.1. Peperomia tetraphylla var. tenera (Miq.) Yunck., Bol. Inst. Bot. (São Paulo) 3: 179. 1966. Material examinado: Rio Preto, trilha para o Ninho da Égua, 2.V.2009, fl., D. Monteiro et al. 529 (CESJ).

Peperomia tetraphylla var. tenera caracterizase pelos ramos com tricomas hirtos no ápice e longo vilosos na base, medindo $0,5-1 \mathrm{~mm}$ compr., e pelas folhas hirtas em ambas as faces e ciliada em toda a margem. Esta variedade é registrada apenas para as Regiões Sudeste e Sul do Brasil (Monteiro \& Guimarães 2008). Na Serra Negra foi encontrada com flor em maio, em interior de mata, próximo a cachoeiras.
12.2. Peperomia tetraphylla (G. Forst.) Hook \& Arn. var. tetraphylla, Bot. Beechey Voy. 97. 1832. Material examinado: Rio Preto, trilha para a Cachoeira do Marciano, 14.X.2008, fl., N.L. Abreu \& C.N. Matozinhos 293 (CESJ).

Peperomia tetraphylla var. tetraphylla é reconhecida pela presença de tricomas hirtos da base até o ápice dos ramos e pela lâmina foliar hirta a glabrescente em ambas as faces, ciliada em toda a margem. Possui ampla distribuição, ocorrendo em países paleotropicais e neotropicais (Monteiro \& Guimarães 2008). No Brasil é facilmente encontrada 
em formações florestais e campestres. Na Serra Negra foi coletada com flor em outubro, apenas em campo com solo quartizítico.

12.3. Peperomia tetraphylla var. valantoides (Miq.) Yunck., Bol. Inst. Bot. (São Paulo) 3: 178. 1966.

Material examinado: Rio Preto, Burro de Ouro, 2158'11'S 4353'21'W, 20.V.2006, fl., P.L. Viana et al. 2052 (CESJ, RB); Ninho da Égua, 14.X.2007, fl. e fr., S.A. Roman et al. 36 (CESJ).

Peperomia tetraphylla var. valantoides difere da variedade típica por possuir ramos esparsamente hirtos a glabrescentes e lâmina foliar glabra em ambas as faces, cerdosa no ápice ou ciliada apenas na metade superior. Ocorre apenas no Sudeste e Sul do Brasil (Monteiro \& Guimarães 2008). Na área de estudo foi encontrada em interior de mata e em campo com solo quartizítico. Floresce e frutifica todo o ano.

13. Peperomia trinervis Ruiz \& Pav., Fl. Peruv. 1: 32, tab. 50, fig. b. 1798.

Epífita; ramos ascendentes, vilosos, tricomas ca. 0,5 mm compr., alinhados. Folhas alternas, 3-4,5 × 1-1,3 cm, elíptico-lanceoladas, base aguda, decurrente, ápice acuminado, ciliado, face adaxial glabra a esparsamente vilosa, abaxial vilosa; nervuras 3; pecíolo ca. $7 \mathrm{~mm}$ compr., com linha de tricomas vilosos. Espigas 7-9 cm compr., axilares ou terminais, 1-3, eretas; pedúnculo 7-10 mm compr., glabro; raque foveolada, verrucosa, glandulosa, glabra. Fruto globoso-ovóide, com ápice oblíquo e estigma subapical.

Material examinado: Rio Preto, Cânion do Funil, 10.XI.2005, fl., K. Antunes et al. 209 (CESJ, RB).

Material adicional examinado: MINAS GERAIS: Passa Quatro, Estrada para Toca do Lobo, 21.VII.2005, fl. e fr., L.D. Meireles et al. 1889 (RB, UEC).

Peperomia trinervis pode ser reconhecida pelos tricomas vilosos, folhas alternas, elipticolanceoladas e espigas longas. Assemelha-se a $P$. diaphanoides, diferindo pela presença de tricomas nos ramos e nas folhas que são mais elípticas e pelo pedúnculo ligeiramente menor. Assim como P. martiana, ocorre de forma disjunta, nas Regiões Sudeste e Sul do Brasil, onde é rara e pouco frequente, e em áreas de floresta amazônica fora do país (Monteiro \& Guimarães 2008). Na Serra Negra foi coletada com flor em novembro, em área úmida e sombreada. Ilustração em Monteiro \& Guimarães (2008).
14. Peperomia urocarpa Fisch. \& C.A. Mey., Index Seminum (St. Petersburg) 4: 42. 1838.

Terrestre ou rupícola; ramos pubescentes, tricomas ca. 0,5 mm compr. Folhas alternas, 2,5-4 $\times 2-3,5 \mathrm{~cm}$, ovadas, base obtusa a arredondada, ápice agudo, pubescente em ambas as faces; margem ciliada; nervuras 5; pecíolo 1,5-3,5(-4) cm compr., pubescente;. Espigas (2,5-)4-6 cm compr., eretas, 1-2, terminais ou opostas às folhas; pedúnculo 2-3 cm compr., pubescente; bráctea peduncular ca. 4,5 mm compr., falcado-lanceolada, glandulosa, pubescente, cerdosa no ápice; raque foveolada, lisa, glabra. Fruto elíptico, com ápice rostrado e estigma subapical.

Material selecionado: Rio Preto, Funil, 17.IV.2006, fl. e fr., K. Antunes et al. 216 (CESJ, RB); interior do Cânion do Funil, 27.I.2007, fl., C.N. Matozinhos et al. 316 (CESJ, RB).

Peperomia urocarpa se distingui facilmente pelos tricomas pubescentes, folhas alternas, ovadas, com a base obtusa a arredondada, e pelos frutos rostrados no ápice, como recentemente ilustrado (Monteiro \& Guimarães 2008). Possui ampla distribuição sendo encontrada do México até a Argentina; no Brasil ocorre em todas as Regiões, com mais frequência no Sudeste e Sul, sendo bastante comum em florestas úmidas (Carvalho-Silva 2008). Foi citada na lista de espécies ameaçadas de extinção do estado de Minas Gerais como quase ameaçada (anexo VIII, Biodiversitas 2007), porém como a espécie possui ampla e expressiva distribuição e este estado de conservação não foi confirmado na revisão das espécies brasileiras de Rhynchophorum (CarvalhoSilva 2008), recomenda-se aqui a retirada do nome deste táxon da lista. Na região foi encontrada em mata úmida e sombreada, florescendo e frutificando de janeiro e abril.

15. Piper amalago L., Sp. Pl. 1: 29. 1753.

Arbusto ca. 2,5 m alt.; ramos glabrescentes em direção a base. Folhas 5,5-8,5 × 2,5-5, ovadas, rômbico-ovadas a elíptico-ovada, base simétrica, aguda a obtusa, ápice agudo, face adaxial glabra, abaxial pubérula ao longo das nervuras; acródroma-basal, nervuras 5; pecíolo 0,8-1,2 cm compr., pubérulo. Espigas 4,5-7,5 $\mathrm{cm}$ compr., eretas; pedúnculo 2-2,5 cm compr., pubérulo a glabrescente; raque pubérula; bractéola arredondado-peltada, franjada na margem inferior. Fruto ovóide, lateralmente anguloso-sulcado, agudo no ápice, glabro; estilete ausente. 
Material examinado: Lima Duarte, Serra Negra, estrada para Monte Verde de Cima, 2155'20"S 4347'30'W, 15.XI.2008, fl. e fr., F.R.G. Salimena \& P.H. Nobre 2742 (CESJ).

Piper amalago é facilmente reconhecida pelas folhas ovadas de tamanho médio, com todas as nervuras partindo de um mesmo ponto na base e se dirigindo ao ápice, e pelas espigas eretas. A espécie foi ilustrada na flora da Venezuela e ocorre em países paleotropicais e neotropicais (Steyermark 1984). Possui vários nomes populares e usos como medicinal, na forma de banhos e chás (Guimarães \& Valente 2001; Guimarães \& Giordano 2004). É comum e amplamente distribuída em todas as Regiões do Brasil sendo encontrada em matas de galeria circundadas por cerrado, clareiras e bordas de mata e rios das florestas estacional decidual, ombrófila mista, ombrófila densa e restingas (Falcão et al. 1977; Guimarães \& Valente 2001; Guimarães et al. 2007). $\mathrm{Na}$ área de estudo foi coletada em interior de mata com flor e fruto em novembro.

16. Piper anisum (Spreng.) Angely, Flora Descritiva do Paraná 2: 387. 1978.

Fig. 2a-b

Arbusto 1-2,5 m alt.; ramos glabrescentes. Folhas 11-17 × 3-6 cm, elíptico-oblongas a elíptico-lanceoladas, base obtusa a cordada, ligeiramente assimétrica, um lado diferindo do outro 1-2 $\mathrm{mm}$, ápice agudo, face adaxial glabra, abaxial hirtela ao longo das nervuras; broquidódroma, nervuras secundárias 10-12 pares dispostos até o ápice; pecíolo 4-10 mm compr., hirtelo. Racemos 6,5-10 cm compr., eretos; pedúnculo 5-7 mm compr., glabro; raque estriada, papilosa; pedicelo papiloso; bractéola sacado-galeada, glabra. Fruto ovóide, tetragonal, lateralmente anguloso-sulcado, agudo no ápice, glabro; estilete ausente.

Material selecionado: Lima Duarte, RPPN Fazenda Serra Negra, 25.X.2009, fl., S.M. Dutra et al. 13 (CESJ). Rio Preto, Serra da Caveira D'anta, Fazenda Tiririca, 15.XI.2003, fr., F.R. Salimena et al. 1203 (CESJ, RB); Gruta do Funil, 10.XI.2005, fl., K. Antunes et al. 191 (CESJ); trilha para o Ninho da Égua, 2.V.2009, fl. e fr., D. Monteiro et al. 532 (CESJ).

Piper anisum pode ser reconhecida pelas dimensões e forma elíptico-oblonga a elípticolanceolada das folhas, hirtela ao longo das nervuras da face abaxial, e pelos racemos com raque e pedicelo papilosos, caracteres que a difere de $P$. corcovadensis. É encontrada apenas no Sudeste e em alguns estados do Nordeste do Brasil, ocorrendo de forma esparsa em áreas de floresta ombrófila densa, em diferentes gradientes altitudinais; mais raramente habita áreas com influencia fluviomarinhas (Guimarães \& Giordano 1997; Guimarães et al. 2011). Conhecida popularmente como jaborandi, é ritualística e possui ações anestésica e diurética (Guimarães \& Monteiro 2006). Na região foi coletada em floresta altomontana, florescendo e frutificando praticamente todo o ano.

17. Piper arboreum var. hirtellum Yunck., Ann. Missouri Bot. Gard. 37(1): 64. 1950.

Arbusto com ramos pubérulos, tricomas ca. 0,5 mm compr. Folhas 20-24 × 5-6 cm, lanceoladas, base assimétrica, um lado 1,5-2 cm mais curto em relação ao outro, obtusa em um dos lados ou ambos agudos e decurrentes, ápice agudoacuminado, face adaxial glabra, abaxial puberula; broquidódroma, nervuras secundárias 8-10 pares dispostos até o ápice; pecíolo 1-1,5 cm compr., com bainha alongada e alada por toda a sua extensão, pubérulo; Espigas 6-8 × 0,2-0,3 cm, apiculadas, eretas; pedúnculo 0,5-1 cm compr., pubérulo; raque glabra; bractéola triangular-peltada, franjada em toda a margem. Fruto oblongo, truncado no ápice, glabro; estilete ausente.

Material examinado: Rio Preto, Serra Negra, Funil, 17.IV.2006, fr., K. Antunes et al. 215 (CESJ).

Piper arboreum var. hirtellum caracterizase pela presença de tricomas pubérulos, folhas lanceoladas a elíptico-lanceladas, assimétricas na base e pelas espigas eretas, apiculadas, geralmente menores do que as folhas. Ocorre em Honduras, Costa Rica, Panamá, Trinidade, Antilhas, Colômbia, Venezuela, Guiana, Suriname, Equador, Bolívia, e de forma bastante comum em quase todo o Brasil (Monteiro \& Guimarães 2009), recebendo vários nomes populares dependendo da região. Habita matas alagadiças e no interior ou borda de floresta ombrófila densa (Guimarães \& Monteiro 2006). É utilizada em banhos e como carminativa, anestésica e contra bronquite, na forma de chás (Guimarães \& Monteiro 2006). Na Serra Negra é pouco frequente e foi coletada com fruto em abril, em mata úmida.

18. Piper caldense C.DC., Linnaea 37: 343. 1872.

Arbusto ca. 1,5 m alt., glabro, castanhoglanduloso. Folhas 14-20 × 2,5-4, lanceoladas, base decurrente, ligeiramente assimétrica, um lado ca. $2 \mathrm{~mm}$ mais curto em relação ao outro, ápice agudo; broquidódroma, nervuras secundárias 8-10 pares dispostos até o ápice; pecíolo ca. $1 \mathrm{~cm}$ 


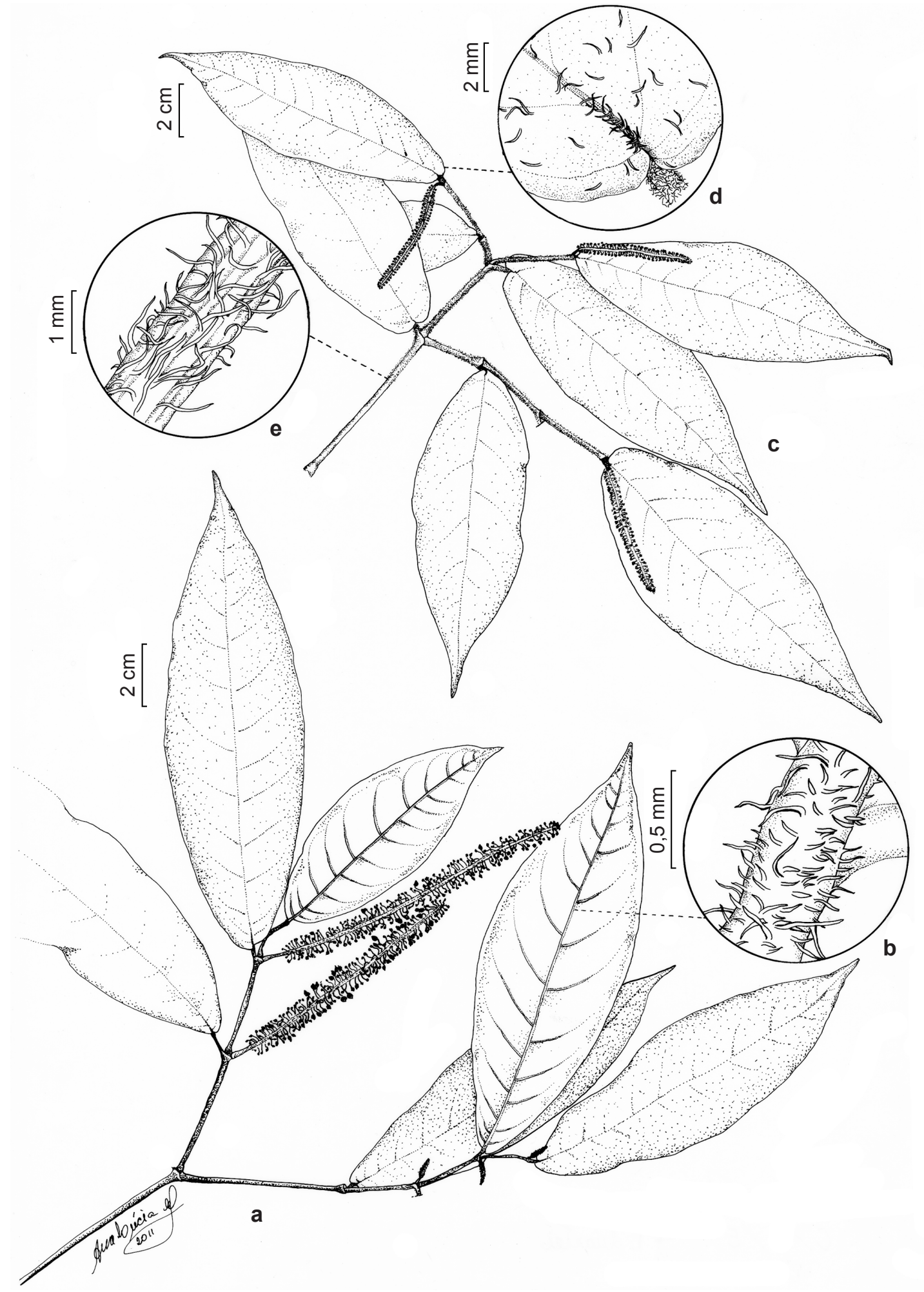

Figura 2 - a-b. Piper anisum (Monteiro 532) - a. parte do ramo com racemos; b. tricomas da face abaxial das folhas. c-e. P. duartei (Monteiro 379) - c. parte do ramo com racemos; d. tricomas da face adaxial das folhas; e. tricomas do ramo. Figure 2 - a-b. Piper anisum (Monteiro 532) - a. branch with racemes; b. trichomes of the lower leaf suface. c-e. P. duartei (Monteiro $379)$ - c. branch with racemes; $d$. trichomes of the upper leaf surface; e. trichomes of the branch. 
compr., sem bainha alada; Espigas 3-4 cm compr., pêndulas; pedúnculo 1-1,3 cm compr.; bractéola triangular-subpeltada, densamente amarelofranjada em toda a margem. Fruto ovóide, agudo no ápice, glabro; estilete curto, ca. 0,3 $\mathrm{mm}$ compr. Material selecionado: Rio preto, Serra do Funil, interior do Cânion, 20.VIII.2004, fl., C.N. Matozinhos 3 et al. (CESJ, RB); RPPN Mato Limpo, mata da cachoeira, 6.X.2007, fr., F.R.G. Salimena \& P.H. Nobre 2499 (CESJ).

Piper caldense diferencia-se das demais espécies estudadas por ser um arbusto glabro, castanho glanduloso, com folhas lanceoladas, relativamente longas e espigas pequenas e pêndulas, como ilustrado por Carvalho-Silva \& Guimarães (2009). A bractéola triangular, amarelo-franjada e o estilete persistente no fruto também contribuem para o diagnóstico. Ocorre apenas no Brasil, de Pernambuco a Santa Catarina, em altitudes relativamente elevadas, habitando matas ciliares em floresta ombrófila densa ou cerrado (Guimarães 1994; Guimarães et al. 2007). É conhecida popularmente como paguarandy (Guimarães \& Valente 2001), porém não há referências quanto a sua utilidade. $\mathrm{Na}$ área de estudo foi coletada em interior de mata úmida. Floresce e frutifica de maio a outubro.

19. Piper cernuum Vell., Fl. Flumin. 1: 25, tab. 58. 1829.

Arbusto ca. $3 \mathrm{~m}$ alt.; ramos tomentosos a glabrescentes, tricomas $0,5-1,5 \mathrm{~mm}$ compr., castanhos. Folhas 22-28 × 10-17 cm, ovadoelípticas, base assimétrico-lobada, cordadoauriculada, um lobo $2-3,5 \mathrm{~cm}$ mais curto em relação ao outro, ápice agudo a obtuso, face abaxial tomentoso-pubescente e castanho glandulosa, adaxial glabra; broquidódroma, nervuras secundárias 7-11 pares dispostos até o ápice; pecíolo 3,5-5,5 cm compr., tomentoso, com bainha alongada e alada por toda sua extensão. Espigas $30 \times 0,5 \mathrm{~cm}$, pêndulas; pedúnculo 1,3-2 cm compr., vilosotomentoso a glabrescente; raque glabra; bractéola triangular-subpeltada, densamente franjada em toda a margem. Fruto oblongo, truncado no ápice, denso-pubescente; estilete ausente.

Material examinado: Rio Preto, Serra do Funil, 12.IX.2004, fr., C.N. Matozinhos et al. 98 (CESJ, RB).

Piper cernuum, ilustrada em Guimarães et al. (2007), é facilmente reconhecida pelas folhas magnas, ovado-elípticas e assimétrico-lobadas na base, pecíolo com bainha alada, espigas longas e pêndulas e presença de tricomas tomentosos. É encontrada em vários países da América do
Sul, onde recebe diferentes nomes populares; no Brasil ocorre de forma esparsa em áreas de floresta nas regiões amazônica e atlântica em altitudes relativamente elevadas (Monteiro \& Guimarães 2009). É usada contra picada de cobra e considerada sialagoga e diurética (Guimarães \& Giordano 2004). A Serra do Tabuleiro talvez seja o limite austral da espécie (Guimarães \& Valente 2001), Na região foi encontrada com fruto em setembro, em mata ciliar.

20. Piper chimonanthifolium Kunth, Linnaea 13: 628. 1840.

Arbusto 2-3 m alt.; ramos vilosos, tricomas 1-2 mm compr. Folhas $13-16 \times 3-4,5 \mathrm{~cm}$, elípticolanceoladas, base assimétrica, um lado $2-5 \mathrm{~mm}$ mais curto em relação ao outro, obtusa em ambos os lados ou um deles arredondado-cordado, ápice agudo-acuminado, face adaxial escabra, bulada quando envelhecida, pouco lacunosa, face abaxial vilosa, principalmente ao longo da nervura central, com glândulas castanhas , tricomas não adpressos, áspera ao toque em ambas as faces; margem ciliada, estreitamente revoluta; camptódroma, nervuras secundárias 4-6 pares dispostos até ou pouco acima da porção mediana, não atingindo o ápice; pecíolo ca. $0,5 \mathrm{~cm}$ compr., com bainha basal, densamente viloso. Espigas 5-10 × 0,2-0,3 cm, curvas; pedúnculo 1-1,5 cm compr., viloso; raque glabra; bractéola arredondada a triangular, subpeltada, densamente franjada em toda a margem. Fruto oblongo, truncadodepresso no ápice, glabro; estilete ausente.

Material examinado: Lima Duarte, RPPN Fazenda Serra Negra, trilha para a cachoeira da Divisa B, $21^{\circ} 56^{\prime} 40^{\prime \prime} \mathrm{S}$ 4350'27'W, 1008 m., 29.II.2008, fr., F.R.G. Salimena et al. 2639 (CESJ); idem, Cachoeirinha da Borboleta Azul, 25.X.2008, fl., D. Monteiro et al. 380 (CESJ).

Piper chimonanthifolium distingui-se pela presença de tricomas vilosos, profusamente distribuídos por toda a planta, folhas 3-4 vezes mais longas do que largas com nervuras até a porção mediana, escabras ao toque e densamente castanho glandulosas, com base assimétrica, obtusa a arredondada em ambos os lados, além de apresentar margem ciliada e estreitamente revoluta e espigas curvas. Ocorre na Região Sudeste do Brasil e nos estados da Bahia, Mato Grosso e Mato Grosso do Sul (Guimarães et al. 2011), sendo frequente em áreas abertas e ensolaradas. Na Serra Negra foi encontrada em floresta montana, florescendo e frutificando de outubro a fevereiro. Não foram encontradas citações sobre usos e denominações populares para o táxon. 
21. Piper claussenianum (Miq.) C.DC., Prodr. 16(1): 275.1869.

Fig. 3a-d

Arbusto ca. $2 \mathrm{~m}$ alt.; ramos densamente vilosos, tricomas $0,5-1 \mathrm{~mm}$ compr., não retrorsos Folhas 10-13 × 4-5,5 cm, ovado-elípticas, base assimétrica, um lado 1-3 mm mais curto em relação ao outro, obtusa a arredondada em ambos os lados, ápice agudo-acuminado, face adaxial híspido-escabra, vilosa ao longo das nervuras, áspera ao toque e bulada quando envelhecida, face abaxial lacunosa, castanho-glandulosa, com tricomas vilosos, não adpresso; camptódroma, nervuras secundárias 5-6 pares dispostos até a porção mediana, não atingindo o ápice; pecíolo 0,5-1 cm compr., com bainha basal, viloso. Espigas 11-13 × 0,3 cm, curvas; pedúnculo $11,5 \mathrm{~cm}$ compr., viloso; raque glabra; bractéola arredondado, subpeltada, densamente franjada em toda a margem. Fruto oblongo, truncado-depresso, hispídulo a glabrescente ou no ápice; estilete ausente. Material examinado: Santa Bárbara do Monte Verde, Serra Negra, Fazenda Cachoeira Alta, $21^{\circ} 58$ ' $21^{\prime \prime}$ S $43^{\circ} 50$ '06”'W, 10.II.2007, fl. e fr., F.R.G. Salimena \& P.H. Nobre 2375 (CESJ).

Piper claussenianum pode ser reconhecida pela presença de tricomas vilosos, folhas buladas e lacunosas quando envelhecias e inflorescências curvas. Trata-se de planta bastante rara, encontrada em algumas regiões de Minas Gerais e São Paulo (Guimarães et al. 2011), de forma esparsa e pouco frequente, preferindo locais ensolarados. Não há referências sobre denominação popular e usos.

22. Piper coccoloboides Kunth, Linnaea 13: 666. 1840.

Fig. 3e-g

Arbusto ca. $3 \mathrm{~m}$ alt.; ramos castanho-vilosos, tricomas $2 \mathrm{~mm}$ compr. Folhas $22-28 \times 10-12 \mathrm{~cm}$, elípticas, base assimétrico-lobada, cordado-auriculada, um lobo 2,5-3,5 cm mais curto em relação ao outro, ápice agudo a obtuso, face adaxial tomentosovilosa, abaxial vilosa; broquidódroma, nervuras secundárias 7-11 pares dispostos até o ápice; pecíolo 3,5-5,5 cm compr., com bainha alongada e alada por toda sua extensão, viloso. Espigas 29 $\times 0,5 \mathrm{~cm}$, pêndulas; pedúnculo $1,3 \mathrm{~cm}$ compr., viloso; raque glabra; bractéola triangular, cuculada, subpeltada, densamente franjada em toda a margem. Fruto oblongo, truncado no ápice, densopubescente; estilete ausente.

Material examinado: Rio Preto, Fazenda Tiririca, Serra da Caveira d'anta, 22.II.2004, fr., K. Antunes et al. 16 (CESJ, RB).

Piper coccoloboides caracteriza-se pela dimensão das folhas, que são elípticas e assimétrico- lobadas na base, e pelas espigas pêndulas, do mesmo tamanho ou excedendo as folhas. Assemelhase morfologicamente a $P$. cernuum, diferindo principalmente pelos ramos vilosos e tricomas em ambas as faces da lâmina foliar. É rara e ocorre de forma esparsa apenas no estados brasileiros de Goiás, Minas Gerais, Espírito Santo e no Distrito Federal (CRIA 2009). Na área de estudo foi coletada com fruto em fevereiro, em interior de mata, próximo a curso d'água. Não foram encontradas citações sobre usos e nomes populares.

23. Piper corcovadensis (Miq.) C.DC., Prodr. 16(1): 255. 1869.

Arbusto 1-2 m alt., glabro. Folhas 11-15 $\times 3-5$, elíptico-lanceoladas, base ligeiramente assimétrica um diferindo do outro em 1-2 mm, obtusa em ambos os lados, ápice agudo-acuminado, glabra em ambas as faces; broquidódroma, nervuras secundárias 10-12 pares dispostos até o ápice; pecíolo $5 \mathrm{~mm}$ compr. Racemos $6-8 \mathrm{~cm}$ compr., eretos; pedúnculo 1-1,5 cm compr.; raque estriada; bractéola sacado-galeada. Fruto ovóide, tetragonal, lateralmente anguloso-sulcado, agudo no ápice, estilete ausente.

Material examinado: Lima Duarte, Fazenda Serra Negra, 24.X.2009, fl., J.H.C. Ribeiro et al. 215 (CESJ). Rio Preto, Serra Negra, 2007, fr., A.S.M. Valente \& P.O. Garcia (CESJ 49348).

Piper corcovadensis é um arbusto glabro com folhas longas, elíptico-lanceoladas, e inflorescências em racemos, também longas. Além da ausência de tricomas, o comprimento do pedúnculo diferencia-o de P. anisum, do qual se aproxima. É citada em outros trabalhos como Ottonia propinqua Kunth e conhecida principalmente como chá-bravo, jaborandi ou zebrandim, possuindo dentre outras, ações estomáquica e carminativa (Guimarães \& Giordano 2004; Guimarães \& Monteiro 2006). O táxon foi recentemente ilustrado e ocorre apenas no Brasil do Ceará ao Rio Grande do Sul, sendo relativamente frequente em interior e borda de mata, capoeiras e matas de galeria (Medeiros \& Guimarães 2007). Na região foi coletada com flor em outubro.

24. Piper cubataonum C.DC., Notizbl. Königl. Bot. Gart. Berlin 6: 440. 1917.

Arbusto ca. $1 \mathrm{~m}$ alt.; ramos longo- vilosos, tricomas 1-1,5 mm compr. Folhas 10-14 $\times$ 5-8 cm, ovadas, base arredondado-truncada a cordada, simétrica, ápice agudo-acuminado, 


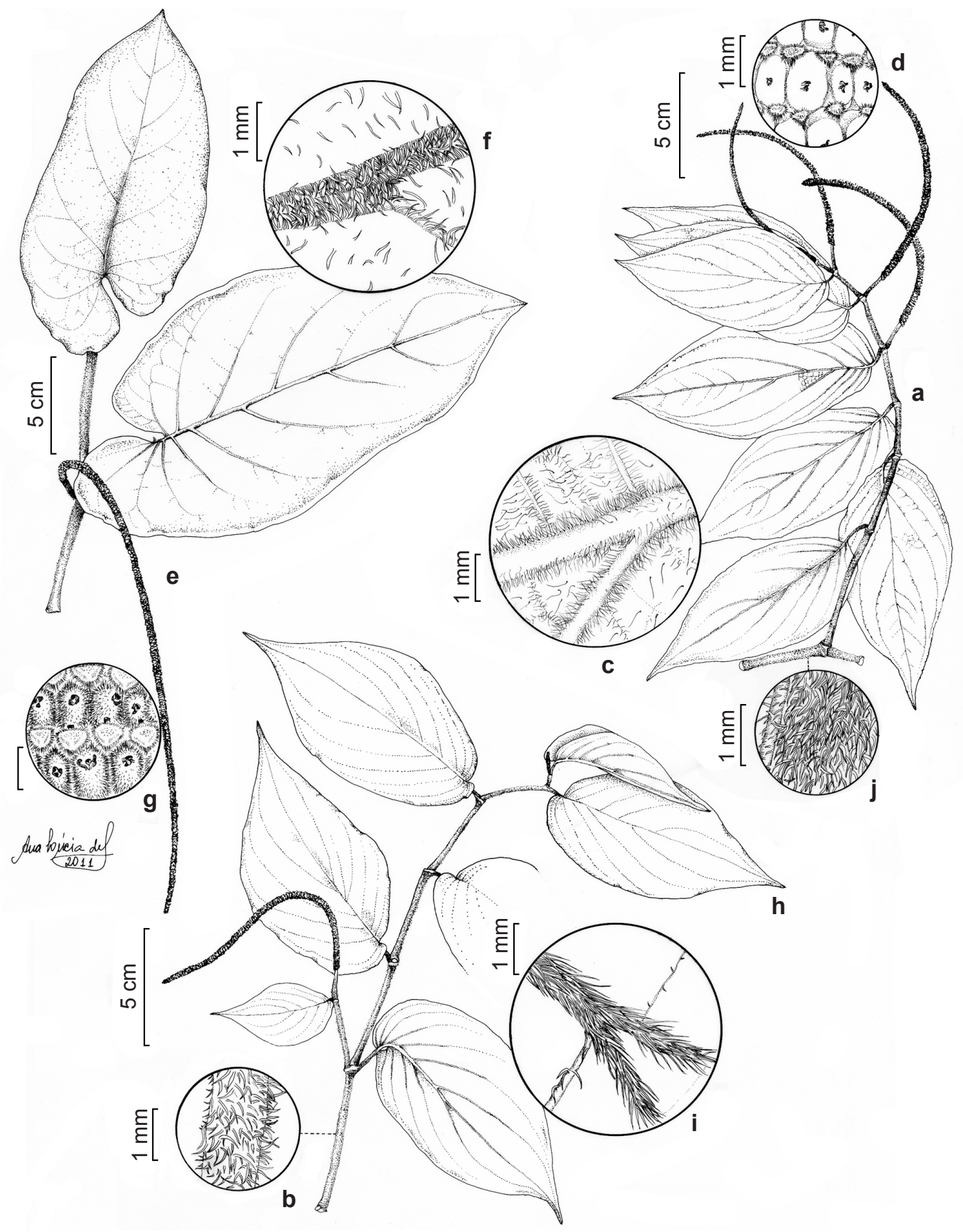

Figura 3 - a-d. Piper claussenianum (Salimena 2375) - a. parte do ramo com espigas; b. tricomas do ramo; c. tricomas da face abaxial da folha; d. detalhe da espiga em frutificação. e-g. P. coccoloboides (Antunes 16) - e. parte do ramo com espiga; f. tricomas da face adaxial da folha; g. detalhe da espiga em frutificação. h-j. P. pauciramosum (Monteiro $510)$ - h. parte do ramo com espiga; i. tricomas da face abaxial da folha; j. tricomas do ramo.

Figure 3 - a-d. Piper claussenianum (Salimena 2375) - a. branch with spike; b. trichomes of the branch; c. trichomes of the lower leaf suface; d. detail of the spike in fruiting. e-g. P. coccoloboides (Antunes 16) - e. branch with spike; f. trichomes of the upper leaf surface; g. detail of the spike in fruiting. h-j. P. pauciramosum (Monteiro 510) - h. branch with spike; i. trichomes of the lower leaf suface; j. trichomes of the branch. 
vilosa em ambas as faces; camptódroma, nervuras secundárias 5-7 pares dispostos até a quarta parte da lâmina, próximas ao ápice; pecíolo 1,5-3,5 cm compr., com bainha alongada em toda sua extensão, viloso. Espigas 4,5-6 × 0,3 $\mathrm{cm}$, eretas; pedúnculo 0,5-1,2 cm compr., viloso; raque glabra; bractéola triangular, subpeltada, glabra. Fruto trigonal, agudo no ápice, glabro; estilete ausente.

Material examinado: Lima Duarte, Fazenda Serra Negra, 25.X.2009, fl, J.H.C. Ribeiro 218 (CESJ). Rio Preto, Serra da Caveira D'anta, Fazenda Tiririca, 15.XI.2003, fr., F.R.G. Salimena et al. 1196 (CESJ, RB).

Piper cubataonum diferencia-se das demais espécies da região pelas folhas ovadas, arredondado-truncadas ou cordadas na base, espigas eretas e pelos tricomas vilosos distribuídos por toda a planta. Os frutos e bractéolas trigonais e glabros também auxiliam na identificação. Foi recentemente ilustrada e possui distribuição bastante esparsa e restrita em regiões de floresta ombrófila densa montana do Sudeste do Brasil (Monteiro \& Guimarães 2009). Na Serra Negra foi encontrada em interior de mata, florescendo e frutificando entre outubro e novembro. Não foram encontradas citações quanto a possíveis usos e denominações populares.

25. Piper duartei E.F.Guim \& M. Carvalho-Silva, Hoehnea 36(3): 432. 2009.

Fig. 2c-e

Arbusto ca. 2 m alt.; ramos vilosos a glabrescentes em direção a base. Folhas 11-14 $\times$ 3,5-5, elíptico-lanceoladas, base ligeiramente assimétrica, um diferindo do outro em 1-2 mm, arredondado-cordada em ambos os lados, ápice agudo, acuminado, vilosas em ambas as faces, tricomas mais densamente distribuídos ao longo da nervura central da face abaxial; broquidódroma, nervuras secundárias 10-12 pares dispostos até o ápice; pecíolo ca. $6 \mathrm{~mm}$ compr., com bainha basal, viloso. Racemos 4-5 cm compr., eretos; pedúnculo ca. $5 \mathrm{~mm}$ compr.; raque estriada, papilosa a hirtela; pedicelo papiloso a hirtelo; bractéola sacado-galeada. Fruto ovóide, tetragonal, lateralmente angulososulcado, agudo no ápice, glabro; estilete ausente.

Material examinado: Lima Duarte, RPPN Fazenda Serra Negra, Cachoeirinha da Borboleta Azul, 25.X.2008, fl., D. Monteiro et al. 379 (CESJ).

Material adicional examinado: BRASIL. ESPÍRITO SANTO: Santa Teresa, 25.XI.1953, fl. e fr., A.P. Duarte 4012 (holótipo RB).

Piper duartei é facilmente reconhecida pelas folhas elíptico-lanceoladas, ligeiramente assimétricas e arredondado-cordadas na base, pelo tamanho dos racemos e principalmente pela presença de tricomas vilosos nos ramos e folhas, detalhe que a diferencia de $P$. anisum e $P$. corcovadensis, que são respectivamente hirtela e glabra. É rara e possui distribuição esparsa e restrita ao Espírito Santo e Minas Gerais (Guimarães et al. 2011) ocorrendo em interior de florestas. $\mathrm{Na}$ Serra Negra foi coletada com flor em outubro, em local úmido e sombreado. É por vezes citada como Ottonia villosa Yunck. e até o momento não possui referencias sobre usos e nomes populares.

26. Piper gaudichaudianum Kunth, Linnaea 13: 639. 1840.

Arbusto ca. $2 \mathrm{~m}$ alt.; ramos pubérulopubescente a escabro, tricomas $0,5-1 \mathrm{~mm}$ compr. Folhas $10-15 \times 3,5-5 \mathrm{~cm}$, elíptico-lanceoladas, base assimétrica, 2-4 mm mais curto em relação ao outro, um dos lados agudo e o outro obtuso, ápice agudo-acuminado, face adaxial híspidoescabra a glabrescente, áspera ao toque, face abaxial pilosa, principalmente ao longo da nervura central, tricomas adpressos, não revoluta, não bulada; camptódroma, nervuras secundárias 5-7 pares dispostos até o terço médio da lâmina, não atingindo o ápice; pecíolo $0,5-1 \mathrm{~cm}$ compr., com bainha basal. Espigas $6-8,5 \times 0,3-0,5 \mathrm{~cm}$, curvas; pedúnculo ca. $1 \mathrm{~cm}$ compr., pubescente; raque glabra; bractéola arredondado a triangular-peltada, densamente franjada em toda a margem. Fruto oblongo, truncado-depresso no ápice, glabro; estilete ausente.

Material examinado: Lima Duarte, RPPN Fazenda Serra Negra, 25.X.2008, fl. e fr., D. Monteiro et al. 386 (CESJ). Rio Preto, RPPN Mato Limpo, Gruta dos Macacos, 6.X.2007, fl., F.R. G. Salimena \& P.H. Nobre 2488 (CESJ).

Piper gaudichaudianum distingue-se pelas folhas assimétricas na base, aguda em um dos lados, ásperas ao toque, com tricomas adpressos na face abaxial; este e outros caracteres diagnósticos da espécie foram recentemente ilustrados (Medeiros \& Guimarães 2007). Ocorre em áreas de floresta atlântica no Paraguai, Argentina e Brasil, onde é frequente e comumente encontrada entre 100-1400 $\mathrm{m}$ de altitude, em locais sombreados ou ensolarados, em matas ou restingas, suportando solos pobres (Guimarães 1994, 1999). É conhecida popularmente como murta ou pariparoba possuindo propriedades antiinflamatória e analgésica (Guimarães \& Valente 2001). Na região foi encontrada com flor e fruto em outubro, no interior de mata e mata ciliar. 
27. Piper Ihotzkyanum Kunth, Linnaea 13: 657. 1840.

Arbusto 1,5-3 m alt., glabro. Folhas 13-19

$\times 3,5-5(-6)$, elíptico-lanceoladas, base aguda a obtusa, ligeiramente assimétrica, um lado ca. $2 \mathrm{~mm}$ mais curto em relação ao outro, ápice agudoacuminado; margem revoluta; camptódroma, nervuras secundárias 3-4 pares dispostos até a porção mediana, não atingindo o ápice; pecíolo $1-1,7(-2,5) \mathrm{cm}$ compr., com bainha alongada por toda sua extensão. Espigas 3,5-6 cm compr., eretas; pedúnculo $0,5-1 \mathrm{~cm}$ compr.; raque glabra; bractéola arredondada a triangular, subpeltada, densamente franjada em toda a margem. Fruto oblongo, truncado-depresso no ápice, glabro; estilete curto, ca. $0,3 \mathrm{~mm}$ compr.

Material selecionado: Lima Duarte, Serra Negra, Fazenda Serra Negra, trilha da cachoeira da Divisa B, 21 ${ }^{\circ} 56^{\prime} 40^{\prime \prime}$ S 4350'27'W, 1008 m., 29.II.2008, fl. e fr., F.R.G. Salimena et al. 2640 (CESJ). Rio Preto, trilha para a cachoeira do Marciano, fr., 13.VII.2008, N.L. Abreu et al. 255 (CESJ); próximo a cachoeira do Ninho da Égua, 1.VI.2006, fl., P.L. Viana et al. 2150 (CESJ, RB); Serra da Caveira D' anta, Fazenda Tiririca, 22.II.2004, fl., A.J. Fernandes Júnior et al. 104 (CESJ, RB).

Piper lhotzkyanum é um arbusto glabro com folhas elíptico-lanceoladas, lustrosas, cujas nervuras secundárias não atingem o ápice da lâmina. Apresenta espigas eretas, com bractéola densamente franjada na margem e estilete persistente no fruto, como ilustrado em Medeiros \& Guimarães (2007). Ocorre na Bahia e no Sul e Sudeste do Brasil, em interior ou borda de mata e às vezes restingas (Guimarães 1994; Guimarães et al. 2011). Conhecida popularmente como pimenteira ou aperta-ruão, possui ações hemolítica e antibacteriana (Guimarães et al. 1992). Foi considerada rara e ameaçada de extinção em Santa Catarina e no Rio de Janeiro (Falcão et al. 1977; Guimarães \& Valente 2001). Na Serra Negra foi encontrada florescendo e frutificando praticamente todo o ano.

28. Piper mollicomum Kunth, Linnaea 13: 648. 1840. Arbusto ca. $2 \mathrm{~m}$ alt., viloso, tricomas $0,5-1 \mathrm{~mm}$ compr. Folhas $13-16 \times 5-6,5 \mathrm{~cm}$, elíptico-lanceoladas, base assimétrica, um lado ca. $2 \mathrm{~mm}$ mais curto em relação ao outro, obtusa a arredondada, ápice agudo, acuminado-falcado, vilosa em ambas as faces, sedosa ao tato, não bulada quando envelhecida; margem ciliada; camptódroma, nervuras secundárias 5-6 pares dispostos até ou abaixo da porção mediana, não atingindo o ápice; pecíolo $0,7-1,5 \mathrm{~cm}$, com bainha basal. Espigas 10-12 $\times 0,3-0,5 \mathrm{~cm}$, curvas; pedúnculo ca. $1,5 \mathrm{~cm}$ compr.; raque glabra; bractéola subtriangular-peltada, densamente franjada em toda a margem. Fruto oblongo, truncado no ápice, lateralmente achatado, glanduloso, pubescentes; estilete ausente.

Material examinado: Rio Preto, Serra da Caveira D'anta, Fazenda Tiririca, 23.II.2004, fl. e fr., K. Antunes et al. 28 (CESJ).

Piper mollicomum assemelha-se a $P$. claussenianum diferindo principalmente pelas folhas elíptico-lanceoladas, sedosos ao tato, nunca buladas ou lacunosas. O táxon que já teve alguns dos seus caracteres diagnósticos ilustrados, ocorre no Panamá, Cuba, Colômbia, Venezuela, Paraguai e Brasil, sendo comum em áreas abertas, sombreadas e também em restingas (Medeiros \& Guimarães 2007). É conhecida popularmente como jaborandi ou pariparoba, possuindo ação antibacteriana (Guimarães \& Valente 2001; Guimarães \& Giordano 2004). Na Serra Negra foi coletada com flor e fruto em fevereiro.

29. Piper pauciramosum Yunck., Bol. Inst. Bot. (São Paulo) 3: 60, fig. 50. $1966 . \quad$ Fig. 3h-j

Arbusto ca. 1,5 m alt.; ramos retrosopubescentes, tricomas ca. $0,5 \mathrm{~mm}$ compr. Folhas 11-14 × 5,5-7,5 cm, elíptico-ovadas, base assimétrica, um lado 2-5 mm mais curto em relação ao outro, lado menor obtuso a arredondado, maior arredondado-cordado, ápice acuminado, face adaxial híspido-escabra a glabrescente, pubescente nas nervuras, áspera ao toque, bulada quando envelhecida, face abaxial viloso-pubescente, com tricomas adpressos, castanho glandulosa; margem rígido-ciliada; camptódroma, nervuras secundárias 6-7 pares dispostos até ou abaixo da porção mediana, não atingindo o ápice; pecíolo $1-1,5 \mathrm{~cm}$ compr., com bainha basal, densamente pubescente. Espigas $10 \times 0,3 \mathrm{~cm}$, curvas; pedúnculo ca. $1 \mathrm{~cm}$ compr., densamente pubescente; raque glabra; bractéola arredondada a triangular, subpeltada, densamente franjada em toda a margem. Fruto oblongo, truncado-depresso, glanduloso e hispídulo no ápice, estilete ausente.

Material examinado: Rio Preto, Serra Negra, trilha para a cachoeira do Marciano, 4.II.2009, fr., D. Monteiro et al. 510 (CESJ, RB).

Piper pauciramosum é endêmica de Minas Gerais com distribuição bastante esparsa. Este é o primeiro registro do táxon depois do holótipo, coletado há mais de 80 anos por Y. Mexia (<http://sweetgum.nybg.org/vh/specimen. php?irn=314927>), no Distrito de Ilhéus do Prata, município de Domingos do Prata, Minas Gerais, na 
Bacia do Rio Doce. Os ramos retrorso-pubescentes, dimensão das folhas, que são escabras ao toque, arredondado-cordada em um dos lados e adpressovilosa na face abaxial, auxiliam na identificação da espécie e a diferenciam de $P$. claussenianum. Não foram encontradas citações sobre usos e denominações populares.

30. Piper pseudopothifolium C.DC., Prodr. 16(1): 289. 1869.

Arbusto 1,5-4 m alt.; ramos vilosos, tricomas 1-1,5(-2,5) mm compr. Folhas 15-22 $\times 3-8 \mathrm{~cm}$, lanceoladas, base assimétrica um lado $1-2,5 \mathrm{~cm}$ mais curto em relação ao outro, arredondado-lobada, auriculada, ápice agudoacuminado, face adaxial glabra, abaxial vilosa ao longo das nervuras; broquidódroma, nervuras secundárias 7-mais pares dispostos até o ápice; pecíolo 2,5-4,5 cm compr., viloso, com bainha alongada e alada por toda a sua extensão. Espigas $13-21 \times 0,2-0,4 \mathrm{~cm}$, pêndulas; pedúnculo $1,5-2 \mathrm{~cm}$ compr., hirto a viloso; raque glabra; bractéola crescente-subpeltada, franjada em toda a margem. Fruto oblongo, truncado-depresso no ápice, denso-pubescente; estilete ausente.

Material examinado: Lima Duarte, RPPN Fazenda Serra Negra, Cachoeirinha da Borboleta Azul, 25.X.2208, fr., D. Monteiro et al. 383 (CESJ). Rio Preto, Fazenda Tiririca, Serra da caveira D'anta, 15.XI.2003, fr., F.R.G. Salimena et al. 1191 (CESJ, RB); RPPN Fazenda Mato Limpo, Gruta dos Macacos, 6.X.2007, fl., F.R.G. Salimena \& P.H. Nobre 2487 (CESJ).

Piper pseudopothifolium é um arbusto viloso, com folhas lanceoladas, assimétricas e arredondado-lobadas na base, com bainha alada no pecíolo e espigas pêndulas, tão longas quanto às folhas. Possui distribuição restrita e esparsa em florestas montana e altomontana no Sudeste do Brasil (Monteiro \& Guimarães 2009). Foi recentemente ilustrada, sendo popularmente conhecida como jaborandi (Medeiros \& Guimarães 2007). Não há referencias quanto a sua utilidade. $\mathrm{Na}$ região foi coletada em interior de mata e próximo a curso d'água, florescendo e frutificando entre outubro e novembro.

31. Piper richardiifolium Kunth, Linnaea 13: 669. 1840.

Arbusto 1-3 m alt.; ramos glabros. Folhas $22-35 \times 7-17 \mathrm{~cm}$, ovado-elípticas a oblongolanceoladas, base fortemente assimétrica, um lado $2-4 \mathrm{~cm}$ mais curto em relação ao outro, cordado-auriculada, ápice agudo, face adaxial glabra, abaxial hirtela a glabrescente nas nervuras; broquidódroma, nervuras secundárias 7-8 pares dispostos até o ápice; pecíolo 6-9 $\mathrm{cm}$ compr., glabro, com bainha alongada e alada por toda sua extensão. Espigas $21-35 \times 0,3-0,5 \mathrm{~cm}$, pêndulas; pedúnculo $2-3 \mathrm{~cm}$ compr., glabro; raque glabra; bractéola triangular, subpeltada, franjada. Fruto oblongo, truncado-depresso no ápice, densopubescente; estilete ausente.

Material examinado: Lima Duarte, Fazenda Serra Negra, 22.II.2008, fr., F.R.G. Salimena et al. 2621 (CESJ); Cachoeira da Mamãe Oxum, 21 56’06”'S 43 50'12”W, 2.III.2008, fr., F.R.G. Salimena et al. 2683 (CESJ). Rio Preto, Funil, Serra da Caveira d'anta, arredores da Fazenda Tiririca, 22.II.2004, fr., L.C. S. Assis et al. 998 (CESJ, RB); Funil, mata do terreno da Dona Lúcia, 17.IV.2006, fl. e fr., K. Antunes 212 (CESJ); Fazenda Santa Luzia, 21 58'40”S 43 52’30”'W, 31.VI.2007, fl., F.R.G. Salimena \& P.H. Nobre 2462 (CESJ).

Piper richardiifolium é um arbusto glabro, caracterizado pelas folhas grandes, ovado-elípticas a oblongo-lanceoladas, assimétricas e cordadoauriculadas na base, com bainha alada no pecíolo e espigas pêndulas com o mesmo comprimento da lâmina foliar, como ilustrado por Medeiros \& Guimarães (2007). Pode ser confundida com $P$. cernuum, diferindo pelos ramos e folhas glabras em ambas as faces, ou estas apenas hirtelas na face abaxial. Ocorre apenas no Brasil de forma pouco frequente em áreas de floresta ombrófila densa, da Bahia a Santa Catarina (Monteiro \& Guimarães 2009). É conhecida popularmente como pau-de-junta, possuindo possivelmente a Serra do Tabuleiro como limite austral (Guimarães \& Valente 2001). Não há referências quanto a seu uso. $\mathrm{Na}$ área de estudo foi encontrada em interior de mata, próximo a curso d'água, frutificando e florescendo de fevereiro a maio.

32. Piper solmsianum C.DC., Prod. 16(1): 291. 1869. Arbusto 1-2 m alt., glabro. Folhas 10-19 × 5,5-12 cm, ovadas, base simétrica ou ligeiramente assimétrica, truncado-arredondada, ápice agudo; camptódroma, nervuras secundárias 6-8 pares dispostos até o ápice; pecíolo 2-6 $\mathrm{cm}$ compr., com bainha alongada por toda sua extensão, por vezes alada e membranáceo-hialina. Espigas 5-7 $\times 0,3-0,5 \mathrm{~cm}$, eretas; pedúnculo $1-1,5 \mathrm{~cm}$ compr.; raque glabra; bractéola arredondada, subcrescentepeltada, vilosa na inferior. Fruto trigonal, glabro; estilete ausente.

Material selecionado: Lima Duarte, RPPN Fazenda Serra Negra, 25.X.2008, fr., D. Monteiro et al. 389 (CESJ). Rio Preto, região do Burro de Ouro, 21 ${ }^{\circ} 58^{\prime} 11^{\prime \prime}$ 'S 435'ㄹ'”, 20.V.2006, fr., P.L. Viana et al. 2058 
(CESJ); trilha para a cachoeira do Marciano, 4.II.2009, fr., D. Monteiro et al. 517 (CESJ); trilha para o Ninho da Égua, 2.V.2009, fr., D. Monteiro et al. 530 (CESJ).

Piper solmsianum pode ser reconhecida pelas folhas grandes e ovadas com bainha alada no pecíolo, espigas eretas, bractéola arredondada, vilosa apenas na face inferior e fruto trigonal, glabro. Foi recentemente ilustrada e possui ação diurética, sendo conhecida popularmente como caapeba ou pariparoba (Medeiros \& Guimarães 2007). Ocorre apenas no Brasil em formações florestais da Bahia ao Rio Grande do Sul (Guimarães et al. 2011). Na Serra Negra foi coletada em interior de floresta ombrófila altomontana e em mata ciliar. Floresce e frutifica praticamente todo o ano.

33. Piper tectoniifolium Kunth, Linnaea 13: 661. 1840.

Arbusto 1-3,5 m alt., pubescente, tricomas até $0,5 \mathrm{~mm}$ compr. Folhas $13-28 \times 8-17 \mathrm{~cm}$, ovadas, base arredondada, assimétrica, um lado ca. $5 \mathrm{~mm}$ mais curto em relação ao outro, ápice agudo; broquidódroma, nervuras secundárias 4-5(-7) pares dispostos até a porção mediana, não atingindo o ápice; pecíolo 1,5-3 cm compr., com bainha alongada até a porção mediana. Espigas 8-11 × 0,5 cm, eretas; pedúnculo 1,5-2,5 cm compr.; raque glabra; bractéola arredondado-peltada, franjada. Fruto oblongo, densamente castanho-pubescente; estilete ausente.

Material selecionado: Lima Duarte, RPPN Fazenda Serra Negra, 22.II.2008, fr., F.R.G. Salimena et al. 2610 (CESJ). Rio Preto, Serra da Caveira D'anta, Fazenda Tiririca, 15.XI.2003, fl., F.R.G. Salimena et al. 1151 (CESJ, RB); Cânion, próximo a Gruta do Funil, 10.XI.2005, fl., $K$. Antunes et al. 189 (CESJ, RB); Fazenda Santa Lúcia, 2158'40"S 4352'30"W, 31.VI.2007, fl., F.R.G. Salimena \& P.H. Nobre 2461 (CESJ); trilha para a Cachoeira do Marciano, 4.II.2009, fr., D. Monteiro et al. 518 (CESJ). Santa Bárbara do Monte Verde, Fazenda Cachoeira Alta, 2157'57'S 4350'29'W, 1089 m.s.m, 15.II.2007, fr., F.R.G. Salimena \& P.H. Nobre 2419 (CESJ).

Piper tectoniifolium, ilustrada por Medeiros \& Guimarães (2007), distingui-se facilmente das demais espécies ocorrentes na região pela presença de tricomas pubescentes densamente distribuídos por toda a planta, pelas folhas largo-ovadas, arredondadas e ligeiramente assimétricas na base, com nervuras dispostas até a porção mediana, pelas espigas longas e eretas, bractéola arredondadofranjada e fruto oblongo, pubescente. Ocorre apenas no Brasil, em todos estados da Região Sudeste, Bahia e Distrito Federal (Guimarães et al. 2011). $\mathrm{Na}$ área de estudo foi encontrada em borda de mata úmida, próximo a curso d'água e em interior da mata. Floresce e frutifica de outubro a maio. Não foram encontrados usos ou nomes populares.

34. Piper viminifolium Trel., Publ. Field Mus. Nat. Hist., Bot. Ser. 22(1): 12. 1940.

Arbusto ca. $2 \mathrm{~m}$ alt., glabro, desprovido de glândulas. Folhas 10-13 × 2,2-3 cm, oblongolanceoladas, lanceoladas, base aguda a obtusa, simétrica, ápice acuminado; broquidódroma, nervuras secundárias 6-8 pares dispostos até o ápice; pecíolo 0,7-1,3 cm compr., com bainha alongada, não alada. Espigas $5 \times 0,3 \mathrm{~cm}$, eretas; pedúnculo ca. $0,5 \mathrm{~cm}$ compr.; raque glabra; bractéola triangular, subpeltada, glabra. Fruto trigonal, glabro; estilete ausente.

Material examinado: Rio Preto, trilha para a cachoeira do marciano, 4.II.2009, fl. e fr., D. Monteiro et al. 516 (CESJ).

Piper viminifolium é um arbusto totalmente glabro reconhecido pelas folhas oblongo-lanceoladas a lanceoladas, bractéolas crescente-subpeltadas, glabras e pelos frutos trigonais também glabros, como ilustrado por Carvalho-Silva \& Guimarães (2009). Ocorre apenas no Brasil, em Goiás, Minas Gerais, Paraná e Santa Catarina (Guimarães et al. 2011), em áreas de floresta ombrófila densa e matas de galeria, de forma esparsa e pouco frequente. Trata-se de espécie rara, citada como deficiente de dados na lista de espécies ameaçadas de extinção do estado de Minas Gerais (Biodiversitas 2007) e considerada vulnerável em Santa Catarina, onde é conhecida popularmente como murta (Guimarães \& Valente 2001). Seus usos são desconhecidos até o momento. $\mathrm{Na}$ área de estudo foi coletada em borda de mata com flor e fruto em fevereiro.

\section{Agradecimentos}

Aos auxílios financeiros concedidos a FAPEMIG (CRA 1891/06; CRA-APQ 1810-5.02/07) e o CNPq (processo 551462/2008-6). Aos curadores dos herbários consultados. A todos os funcionários e bolsistas do herbário CESJ, em especial à Dra. Fátima R.G. Salimena, a amizade, infra-estrutura e apoio nos trabalhos de campo. Ao amigo Dr. Luiz Menini Neto as sugestões no manuscrito. À ilustradora botânica Ana Lúcia de Souza.

\section{Referências}

Abreu, N.L. \& Menini Neto, L. 2010. As subfamílias Vanilloideae e Orchidoideae (Orchidaceae) em um fragmento da Serra da Mantiqueira, Minas Gerais, 
Brasil. Boletim de Botânica da Universidade de São Paulo 28: 15-33.

Abreu, N.L.; Menini Neto, L. \& Konno, T.U.P. 2011. Orchidadeae das Serras Negra e do Funil, Rio Preto, Minas Gerais, e similaridade florística entre formações campestres e florestais do Brasil. Acta Botânica Brasilica 25: 58-70.

Biodiversitas. 2007. Revisão das listas das espécies da flora e da fauna ameaçadas de extinção do estado de Minas Gerais. Vol. 2. Relatório final. Fundação Biodiversitas, Belo Horizonte. 104p.

Carvalho-Silva, M. 2008. Peperomia Ruiz \& Pav. no Brasil: morfologia e taxonomia do subgênero Rhynchophorum (Miq.) Dahlst. Tese de Doutorado. Instituto de Pesquisas Jardim Botânico do Rio de Janeiro/Escola Nacional de Botânica Tropical, Rio de Janeiro. 145p.

Carvalho-Silva, M. \& Guimarães, E.F. 2009. Piperaceae do Parque Nacional da Serra da Canastra, Minas Gerais, Brasil. Boletim de Botânica da Universidade de São Paulo 27: 235-245.

Costa, C.M.R.; Hermann, G.; Martins, C.S.; Lins, L.V. \& Lamas, I. 1998. Biodiversidade em Minas Gerais: um atlas para sua conservação. Fundação Biodiversitas, Belo Horizonte. 94p.

CRIA(Centro de Referência em Informação Ambiental). 2009. SpeciesLink. Disponível em <http://splink. cria.org.br/>. Acesso em 10 Dez 2011.

Drummond, G.M.; Martins, C.S.; Machado, A.B.M.; Sebaio, F.A. \& Antonini, Y. 2005. Biodiversidade em Minas Gerais, um atlas para sua conservação. 2ed. Fundação Biodiversitas, Belo Horizonte. 222p.

Falcão, C.L.; Guimarães, E.F.; \& Costa, C.G. 1977. Piperaceae do município do Rio de Janeiro I: o gênero Piper L. Arquivos do Jardim Botânico 20: 145-188.

Feliciano, E.A. \& Salimena, F.R.G. 2011. Solanaceae na Serra Negra, Rio Preto, Minas Gerais. Rodriguésia 62: $55-76$.

Guimarães, E.F. 1994. In: Lima, M.P.M. de \& GuedesBruni, R.R. 1994. Reserva Ecológica de Macaé de Cima: Nova Friburgo, RJ: aspectos florísticos das espécies vasculares. Vol. 1. Jardim Botânico, Rio de Janeiro. Pp. 327-348.

Guimarães, E.F. 1999. Piperaceae. In: Melo, M. M. R. F.; Barros F.; Chiea, S. A. C.; Kirizawa, M; JungMendaçolli, S.L. \& Wanderley, M. G. L. Flora fanerogâmica da Ilha do Cardoso. Vol. 6. Instituto de Botânica, São Paulo. Pp. 15-43.

Guimarães, E.F.; Carvalho-Silva, M. \& Cavalcanti, T.B. 2007. Piperaceae. In: Rizzo, J.A. Flora dos estados de Goiás e Tocantins. Vol. 32. Coleção Rizzo, Goiânia. Pp. 7-67.

Guimarães, E.F.; Carvalho-Silva, M.; Monteiro, D. \& Medeiros, E.S. 2011. Piperaceae. In: Forzza, R.C. et al. (eds.). Lista de espécies da flora do Brasil. Jardim Botânico do Rio de Janeiro. Disponível em
$<$ http://floradobrasil.jbrj.gov.br/2011/>. Acesso em 10 Dez 2011.

Guimarães, E.F. \& Giordano, L.C.S. 1997. Piperaceae. In: Marques, M.C.M.; Vaz, A.S.F. \& Marquete, R. Flórula da Apa Cairuçu, Parati, RJ: espécies vasculares. Vol. 14. Série Estudos e Contribuições, Rio de Janeiro. Pp. 396-439.

Guimarães, E.F. \& Giordano, L.C.S. 2004. Piperaceae do Nordeste Brasileiro I: estado do Ceará. Rodriguésia 55: 21-46.

Guimarães, E.F.; Ichaso, C.L.F. \& Costa, C.G. 1984. Piperáceas. 4. Peperomia. In: Reitz, R. (ed.). Flora Ilustrada Catarinense. Herbário Barbosa Rodrigues, Itajaí. Pp. 33-136.

Guimarães, E.F.; Mautone, L.; Magalhães, H.G. \& Guimarães, L.A. 1992. Estudos taxonômico e farmacoquímico e bioensaios de Piper lhotzkyanum Kunth (Piperaceae), uma espécie ocorrente em Minas Gerais. Daphne 2: 7-10.

Guimarães, E.F. \& Monteiro D. 2006. Piperaceae na Reserva Biológica de Poço das Antas, Rio de Janeiro, Brasil. Rodriguésia 57: 567-587.

Guimarães, E.F. \& Valente, M.C. 2001. Piperaceae Piper. In: Reis, A. (ed.). Flora Ilustrada Catarinense. Herbário Barbosa Rodrigues, Itajaí. Pp. 4-104.

Medeiros, E.S.S. \& Guimarães, E.F. 2007. Piperaceae do Parque Estadual de Ibitipoca, Minas Gerais, Brasil. Boletim de Botânica da Universidade de São Paulo 25: 227-252.

Menini Neto, L.; Matozinhos, C.N.; Abreu, N.L.; Valente, A.S.M.; Antunes, K. ; Souza, F.S.; Viana, P.L. \& Salimena, F.R.G. 2009. Flora vascular não-arbórea de uma floresta de grota na Serra da Mantiqueira, Zona da Mata de Minas Gerais, Brasil. Biota Neotropica 9:1-14.

Monteiro, D. \& Guimarães, E.F. 2008. Flora do Parque Nacional do Itatiaia - Brasil: Peperomia (Piperaceae). Rodriguésia 59: 161-195.

Monteiro, D. \& Guimarães, E.F. 2009. Flora do Parque Nacional do Itatiaia, Brasil: Manekia e Piper (Piperaceae). Rodriguésia 60: 999-1024.

Pessini, G.L.; Albiero, A.L.M.; Mourão, K.S.M.; Nakamura, C.V.; Dias-Filho, B.P. \& Cortez, D.A.G. 2003. Análise farmacognóstica de Piper regnelli var. palescens (C.DC.) Yunck.: aspectos botânicos e enfoque físico-químico preliminar. Acta Farmacêutica Bonaerense 22: 209-216.

Samain, M.S.; Mathieu, G.; Wanke, S.; Neinhuis, C. \& Goetghebeur, P. 2008. Verhuellia resisited unraveling its intricate taxonomic history and a new subfa.milial classification of Piperaceae. Taxon 57: 583-587.

Silva, E.M.J. \& Machado, S.R. 1999. Estrutura e desenvolvimento dos tricomas secretores em folhas de Piper regnellii C.DC. (Piperaceae). Revista Brasileira de Botânica 22: 117-124. 
Smith, J.F.; Stevens, A.C.; Tepe, E.J. \& Davidson, C. 2008. Placing the origin of two species-rich genera in the late cretaceous with later species divergence in the tertiary: a phylogenetic, biogeographic and molecular dating analysis of Piper and Peperomia (Piperaceae). Plant Systematics and Evolution 275: 9-30.

Steyermark, J.A. 1984. Piperaceae. Flora de Venezuela. Vol. 2. Editorial Fundación Caracas, Caracas. Pp. 5-619.

Valente, A.S.M.; Garcia, P.O.; Salimena, F.R. \& Oliveira-Filho, A.T. 2011. Composição, estrutura e similaridade florística da Floresta Atlântica, na Serra Negra, Rio Preto - MG. Rodriguésia 62: 321-340. Yuncker, T.G. 1958. The Piperaceae - A Family Profile. Brittonia 10: 1-7.

Yuncker, T.G. 1972. The Piperaceae of Brazil I - Piper: Group I, II, III, IV. Hoehnea 2: 19-366.

Yuncker, T.G. 1973. The Piperaceae of Brazil II - Piper: Grupo V; Ottonia; Pothomorphe; Sarcorhachis. Hoehnea 3: 29-284.

Yuncker, T.G. 1974. The Piperaceae of Brazil III Peperomia; Taxa of uncertain status. Hoehnea 4: 71-413.

\section{Índice de coletores:}

Abreu, N.L. 71 (3), 136, 147 (7), 156 (3), 224 (16), 255 (27), 265 (2), 293 (12.b). Antunes, K. 14 (33), 16 (22), 28 (28), 39 (16), 189 (33), 191 (16), 193 (1), 156 (3), 191 (16), 192 (6), 205 (11), 209 (13), 212 (31), 215 (17), 216 (14). Assis, L.C. 998 (31). Belchior, V. 19 (12.c), 209 (13), 216 (14). Costa 39 (33). Dutra, S.M. 13 (16). Fernandes Júnior, A.J. 104 (27). Matozinhos, C.N. 3 (18), 20 (1), 98 (19), 227 (3), 289 (4), 316 (14). Meireles, L.D. 1889 (13). Menini Neto, L. 249 (1), 280 (3), 281 (5), 657 (9), 663 (11). Monteiro, D. 379 (25), 380 (20), 383 (30), 384 (33), 385 (4), 386 (26), 389 (32), 392 (16), 396 (4), 397 (33), 403 (33), 495 (14), 496 (3), 497 (6), 498 (2), 499 (1), 501 (9), 504 (2), 505 (3), 506 (5), 507 (3), 508 (2), 510 (29), 511 (2), 515 (8), 516 (34), 517 (32), 518 (33), 529 (12.a), 530 (32), 531 (27), 532 (16), 533 (6), 534 (3), 535 (2), 536 (2). Oliveira 54 (32), 62 (27), 80 (4). Ribeiro, J.H.C. 21 (1), 99 (32), 215 (23), 218 (24). Roman, S.A. 33 (2), 36 (12.c). Salimena, F.R.G. 1151 (33), 1191 (30), 1196 (24), 1203 (16), 1279 (18), 1285 (1), 1335 (11), 1340 (10), 1359 (9), 2375 (21), 2395 (3), 2419, 2461 (33), 2462 (31), 2487 (30), 2488 (26), 2499 (18), 2610 (33), 2621 (31), 2639 (20), 2640 (27), 2683 (31), 2742 (15), 2763 (2). Souza, F.S. 704 (27), 743 (2), 746 (2). Valente, A.S.M. s.n.-CESJ 49348 (23). Viana, P.L. 2052 (12.c), 2056 (8), 2058 (32), 2150 (27). 